\title{
Visible Light Induced Photocatalytic Performance of Mn-Sno2@Zno Nanocomposite for High Efficient Cationic Dye Degradation
}

\section{S. Asaithambi}

Alagappa University

P. Sakthivel

Alagappa University

M. Karuppaiah

Alagappa University

V. Balaji

Alagappa University

R. Yuvakkumar

Alagappa University

Ravi G ( $\sim$ gravicrc@gmail.com )

Alagappa University https://orcid.org/0000-0003-4493-1539

\section{Research Article}

Keywords: Mn-SnO2@ZnO heterojunction, Methylene blue and Rhodamine B

Posted Date: March 10th, 2021

DOl: https://doi.org/10.21203/rs.3.rs-298961/v1

License: (9) This work is licensed under a Creative Commons Attribution 4.0 International License.

Read Full License

Version of Record: A version of this preprint was published at Journal of Materials Science: Materials in Electronics on August 3rd, 2021. See the published version at https://doi.org/10.1007/s10854-02106692-x. 


\title{
VISIBLE LIGHT INDUCED PHOTOCATALYTIC PERFORMANCE OF

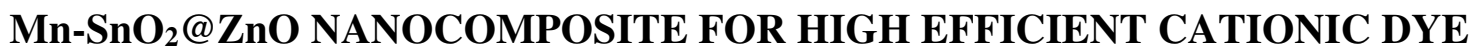 DEGRADATION
}

\author{
S. Asaithambi ${ }^{1,2}$, P. Sakthivel ${ }^{1}$, M. Karuppaiah ${ }^{1}$, V. Balaji ${ }^{1}$, R.Yuvakkumar ${ }^{1}$, G. Ravi ${ }^{1 *}$ \\ ${ }^{1}$ Department of Physics, Alagappa University, Karaikudi-630003, Tamil Nadu, India. \\ ${ }^{2}$ Department of Engineering and Science, Western Norway University of Applied \\ Sciences, Bergen, 5063, Norway
}

*Corresponding author: gravicrc@gmail.com.Telephone: +914565-225206.

\begin{abstract}
In this work, we have synthesized $\mathrm{Mn}$-doped $\mathrm{SnO}_{2} @ \mathrm{ZnO}$ nanocomposite for photo degradation of Methylene blue and Rhodamine B dyes upon visible light irradiation. The crystal structure, functional group, optical absorption, defect related emission, morphology, purity and binding energy state of synthesized samples were identified by using various analytical tools. The optical absorption shift and the reduction of band gap values are confirming the formation of

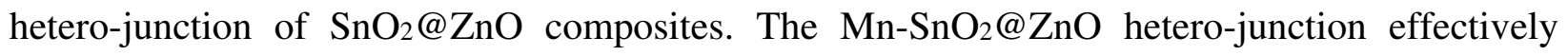
induces the photo-generated charge carrier separation and enriches the charge transfer which helps in enhancing the photo-catalytic activities. The photocatalytic degradation results clearly indicate that the Mn-doped $\mathrm{SnO}_{2} @ \mathrm{ZnO}$ nanocomposite has higher degradation efficiency of $98 \%$ and $92 \%$ for the Methylene blue and Rhodamine B dyes, respectively and is higher than the other synthesized samples. The present study reveals a low cost and highly efficient photocatalyst which works up on visible light irradiation for the purification of waste water from industries.
\end{abstract}

Key words: $\mathrm{Mn}_{-} \mathrm{SnO}_{2} @ \mathrm{ZnO}$ heterojunction, Methylene blue and Rhodamine B

\section{Introduction}

In the present digital era, the energy shortage and the environmental related problems are the two main issues of the livegoods of the modern society. Each year, the Sun releases $1.5 \times 10^{18} \mathrm{~kW}$ h energy to earth which is nearly equal to 28,000 times of the energy consumption 
per year. There are various techniques employed for solar energy utilization indirectly. Among them, photocatalysis is one of the green techniques used to remove the hazardous organic compounds by solar or visible light irradiation. The photocatalysis is modernized after innovating water photolysis of $\mathrm{TiO}_{2}$ in 1972 by Fujishima and Honda [1-3]. Currently, the researchers have focused on developing the low cost, low maintenance and high efficient photocatalysts which work upon solar or visible light irradiation to give pollution free water. In the past three decades, the inorganic metal-oxide $\left(\mathrm{TiO}_{2}, \mathrm{SnO}_{2}, \mathrm{CuO}, \mathrm{WO}_{3}\right.$ and $\mathrm{ZnO}$, etc) based semiconducting materials have propelled a great attention in the field of photocatalysis due to their high catalytic behavior and stability [4-7]. Among the metal oxides, $\mathrm{SnO}_{2}$ is an excellent photocatalyst because it has good transparency, high photosensivity, good stability, and also it is low cost and eco friendly. Several strategies have been employed to reduce the band gap and enhance the visible light absorption like adding impurity ions, surface sensitization and formation of heterojunction with semiconductors [8-9]. Recently, doping impurity ions like $\mathrm{Cu}$, $\mathrm{Co}, \mathrm{Ni}, \mathrm{Mn}$ and $\mathrm{Fe}$ with $\mathrm{SnO}_{2}$ has been found to enhance the photocatalytic activities considerably [10-14]. However, the dopant ions could not enhance the photocatalytic activity considerably in the visible light region. In this regard, the metal doped $\mathrm{SnO}_{2}$ added with another metal oxide to form heterojunction may help to further reduce the band gap energy and recombination of electron hole pairs and enrich the visible light absorption [15].

In recent days, semiconductor hetero-junction was formed to promote the visible light induced photocatalytic application. H. Xia et.al, reported $\mathrm{Fe}_{2} \mathrm{O}_{3} / \mathrm{SnO}_{2}$ based photocatalyst using acid blue 62 dye which underwent a maximum of $98 \%$ degradation [16]. X. Hui-li et. al, synthesized $\mathrm{CuO}-\mathrm{SnO}_{2}$ nanocomposite using acid blue 62 dye under visible light irradiation [17]. S.H. Hwang et.al, prepared $\mathrm{SnO}_{2}-\mathrm{TiO}_{2}$ nano-fiber catalyst for photo-degradation of Rhodamine B [18]. B.C. Zhu et.al, prepared $\mathrm{SnO}_{2} / \mathrm{Fe}_{2} \mathrm{O}_{3}$ heterojunction nanotubes for visible light photocatalytic degradation [19]. H.R. Pouretedal et.al, have reported about a mixture of $\mathrm{ZrO}_{2} / \mathrm{SnO}_{2}$ for degradation of 2-nitrophenol [20]. A. Priyadharsan et.al, prepared ternary $\mathrm{CeO}_{2} / \mathrm{SnO}_{2} / \mathrm{rGO}$ composite for degradation of methylene blue dye using visible light [21]. M.A. Subhan et.al, reported $\mathrm{NiO} \cdot \mathrm{CeO}_{2} \cdot \mathrm{ZnO}$ based composite which revealed the high efficiency photocatalytic application [22]. Karuthapandian et.al, prepared $\mathrm{CuO}-\mathrm{ZnO}$ nanorods and the photocatalytic performance was measured for Congo red and Rhodamine B [23]. J. Lin et al prepared $\mathrm{ZnO} / \mathrm{SnO}_{2}$ photocatalyst and it offered $98 \% \mathrm{MB}$ degradation [24]. Among them, $\mathrm{SnO}_{2}$ - 
$\mathrm{ZnO}$ based heterostructure photocatalyst has received a great attention, because $\mathrm{ZnO}$ is an $n$-type semiconductor, non-toxic, low cost, has good photosensitivity, and high photo-stability with a high exciton binding energy (60 meV) [25]. The $\mathrm{SnO}_{2}-\mathrm{ZnO}$ based heterostructure has good band position which reduces the recombination of charge carrier, stimulate the charge separation and enrich the photocatalytic activity. Earlier, so many researchers reported the $\mathrm{SnO}_{2}$ and $\mathrm{ZnO}$ based composites for visible light based photocatalytic application. However, the metal doped $\mathrm{SnO}_{2} @ \mathrm{ZnO}$ based composites have rarely reported. Recently, the doping of transition metal has great attention in the field of photocatalytic application, because transition metals reduce the particle size, increase the surface area, stimulate the absorption in the visible region and reduce the recombination of electron-hole pairs. Among the transition metals, $\mathrm{Mn}$ is superior because it has different valence states $\left(\mathrm{Mn}^{2+}, \mathrm{Mn}^{3+}\right.$ and $\left.\mathrm{Mn}^{4+}\right)$ which easily replace the $\mathrm{Sn}^{4+}$ ions of the $\mathrm{SnO}_{2}$ lattice. The $\mathrm{Mn}$ ions also produce the above mentioned effects which helped to enrich the photocatalytic activity [26, 27].

In this work, we have synthesized Mn-doped $\mathrm{SnO}_{2} @ \mathrm{ZnO}$ nanocomposites for photocatalytic degradation of cathodic dye under visible light irradiation. For the synthesized samples, structural, optical, composition and morphology were analyzed by using various analytical tools. When compared to $\mathrm{SnO}_{2}, \mathrm{Mn}_{-} \mathrm{SnO}_{2}, \mathrm{SnO}_{2} @ \mathrm{ZnO}$ samples, the $\mathrm{Mn}_{-} \mathrm{SnO}_{2} @ \mathrm{ZnO}$ composite exhibit a maximum degradation efficiency of $98 \%$ and $92 \%$ for Methylene blue and Rhodamine B dyes under visible light irradiation.

\section{Experimental Techniques}

\section{Materials Used}

Tin-chloride-dihydrate $\left(\mathrm{SnCl}_{2} .2 \mathrm{H}_{2} \mathrm{O}\right)$, zinc-chloride $\left(\mathrm{ZnCl}_{2}\right)$, manganese-chloride tetrahydrate $\left(\mathrm{MnCl}_{2} .4 \mathrm{H}_{2} \mathrm{O}\right)$, sodium hydroxide $(\mathrm{NaOH})$ and ammonium hydroxide $\left(\mathrm{NH}_{4} \mathrm{OH}\right)$ chemical reagents were used in this work. All the chemicals with purity of $99.99 \%$ were purchased from Sigma Aldrich and used without any further purification.

\section{Synthesize of $\mathrm{ZnO}$ nanoparticles}

Initially, $0.1 \mathrm{M} \mathrm{ZnCl}_{2}$ was added with $100 \mathrm{ml}$ doubly distilled water and $0.4 \mathrm{M} \mathrm{NaOH}$ solution was added drop wise until the $\mathrm{pH}$ of the solution reach 9. Then, the hydroxide solution 
was stirred for $30 \mathrm{~min}$ at room temperature. Thereafter, the obtained white precipitate was washed with water and ethanol to remove impurities. Then, the precipitate was dried at $100{ }^{\circ} \dot{\mathrm{C}}$ for $12 \mathrm{~h}$ and the resultant powder was annealed at $300^{\circ} \dot{\mathrm{C}}$ for $4 \mathrm{~h}$.

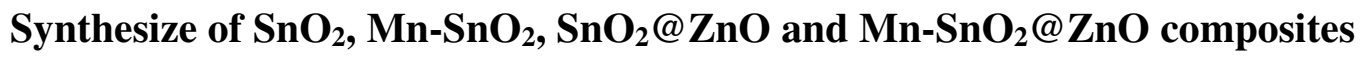

Firstly, $0.1 \mathrm{M} \mathrm{SnCl} 2.2 \mathrm{H}_{2} \mathrm{O}$ was dissolved in $100 \mathrm{ml}$ water and the solution was continuously stirred for $30 \mathrm{~min}$. Then, the $\mathrm{pH}$ was adjusted to 9 by adding $\mathrm{NH}_{3} \mathrm{OH}$ solution drop wise and then the solution was changed to milky white color. Further, the formed tin-hydroxide precipitate was continuously stirred for $3 \mathrm{~h}$ to get homogeneous mixing of the precipitate in the solution and then it was washed with water and ethanol. Finally, the precipitate was dried at $100^{\circ}$ $\mathrm{C}$ for $12 \mathrm{~h}$ and annealed at $600^{\circ} \mathrm{C}$ for $5 \mathrm{~h}$. The same method was followed to synthesize (Mn-5 mM) Mn-SnO 2 nanoparticles. The $\mathrm{SnO}_{2} @ \mathrm{ZnO}$ and $\mathrm{Mn}-\mathrm{SnO}_{2} @ \mathrm{ZnO}$ composites were synthesized by taking $\mathrm{SnCl}_{2} .2 \mathrm{H}_{2} \mathrm{O}$ and $\mathrm{ZnCl}_{2}$ in the ratio of 0.06:0.04 $\mathrm{M}$ respectively.

\section{Photocatalytic analysis}

Photocatalytic performance of the $\mathrm{SnO}_{2}, \quad \mathrm{Mn}-\mathrm{SnO}_{2}, \mathrm{ZnO}, \quad \mathrm{SnO}_{2} @ \mathrm{ZnO}$ and

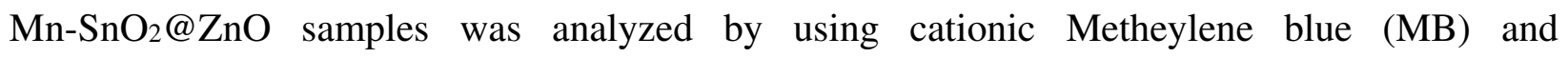
Rhodamine B $(\mathrm{RhB})$ dyes under the visible light irradiation. Firstly, $100 \mathrm{mg}$ of prepared catalyst and $1 \mathrm{ml} \mathrm{MB}$ dye solution were blended with water $(99 \mathrm{ml})$. Then, this solution was sonicated for $10 \mathrm{~min}$ to attain homogeneous mixing of dye solution and the synthesized photo-catalyst. Further, the homogeneously mixed solution was kept in a dark environment to get adsorptiondesorption equilibrium level. In this work, all the photocatalytic experiments were carried out under the irradiation using a halogen lamp. At a regular interval of $20 \mathrm{~min}$ time, $3 \mathrm{ml}$ of reacted suspension was taken to analyze the degradation performance of the solution. The maximum absorbance peak was appeared at $\sim 660 \mathrm{~nm}$ and $\sim 550 \mathrm{~nm}$ for $\mathrm{MB}$ and $\mathrm{RhB}$ dyes respectively and the absorbance was measured with the help of UV-Vis spectroscopy.

\section{Experimental details}

Different analytical techniques have been used to analyze the crystal structure, functional groups, morphology, optical properties, binding energy of the synthesized $\mathrm{SnO}_{2}, \mathrm{Mn}-\mathrm{SnO}_{2}, \mathrm{ZnO}$, $\mathrm{SnO}_{2} @ \mathrm{ZnO}$ and $\mathrm{Mn}-\mathrm{SnO}_{2} @ \mathrm{ZnO}$ composites respectively. The PANalytical X'Pert pro X-ray 
diffractometer $(\lambda=1.5418 \AA$ ) and the FTIR spectrometer (Thermo Nicolet 380 ) were used to identify the crystal structure and functional groups of the synthesized samples. The optical properties were recorded using UV-Vis spectrometer (Thermo Fisher Evolution 220) and photoluminescence spectrometer (Cary Eclipse PL spectrograph) respectively. The surface morphology of the synthesized samples was studied using a field emission scanning electron microscope (FEIQUANDA 200F FESEM). The X-ray Photoelectron Spectroscopy ((Omicron nanotechnology (Oxford instrument)) was used to determine the composition, binding energy and oxidation states of the elements present in the synthesized $\mathrm{SnO}_{2} @ \mathrm{ZnO}$ and $\mathrm{Mn}-\mathrm{SnO}_{2} @ \mathrm{ZnO}$ composite samples.

\section{Results and Discussion}

\section{Powder X-ray diffraction analysis}

The crystal structure of the synthesized $\mathrm{SnO}_{2}, \mathrm{Mn}-\mathrm{SnO}_{2}, \mathrm{ZnO}, \mathrm{SnO}_{2} @ \mathrm{ZnO}$ and

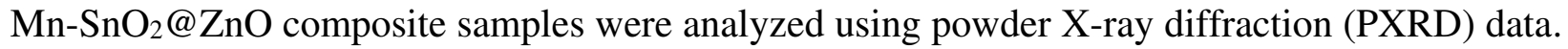
Figure 1 shows the PXRD of synthesized $\mathrm{SnO}_{2}$ and $\mathrm{Mn}-\mathrm{SnO}_{2}$ nanoparticles which revealed the rutile, tetragonal crystal structure with the space group of $P 4_{2} / \mathrm{mnm}$ and it is well matched with JCPDS card. No: 41-1445. The pure $\mathrm{ZnO}$ exhibited the hexagonal wurtzite structure of $\mathrm{ZnO}$ (JCPDS card no. 36-1451) with a crystal space group of P63mc. The $\mathrm{SnO}_{2} @ \mathrm{ZnO}$ and $\mathrm{Mn}-\mathrm{SnO}_{2} @ \mathrm{ZnO}$ composite samples revealed the major intensity peaks of both $\mathrm{SnO}_{2}$ and $\mathrm{ZnO}$ and are depicted in the figure 1. When compared to $\mathrm{SnO}_{2}, \mathrm{Mn}-\mathrm{SnO}_{2}$ and $\mathrm{ZnO}$ samples, the $\mathrm{Mn}$ $\mathrm{SnO}_{2} @ \mathrm{ZnO}$ has lower intensity peaks which may be due to the doping of $\mathrm{Mn}$ in $\mathrm{SnO}_{2}$ sites and the addition of $\mathrm{ZnO}$. The Debye-Scherer formula has been used to determine the average crystallite size of the synthesized samples and the relation is as follows [28, 29]

$$
D=\frac{0.94 \times \lambda}{\beta \cos \theta}(\mathrm{nm})
$$

where, $D$ is crystallite size $(\mathrm{nm}), \lambda$ is X-ray wavelength $(\mathrm{nm}), \beta$ is full width half maximum of diffraction peak (rad), and $\theta$ is diffraction angle (degree). The average crystallite size was found to be $23.3 \mathrm{~nm}, 21.6 \mathrm{~nm}, 27.7 \mathrm{~nm}, 20.6 \mathrm{~nm}$ and $16.7 \mathrm{~nm}$ for the $\mathrm{SnO}_{2}, \mathrm{Mn}-\mathrm{SnO}_{2}, \mathrm{ZnO}, \mathrm{SnO}_{2} @ \mathrm{ZnO}$

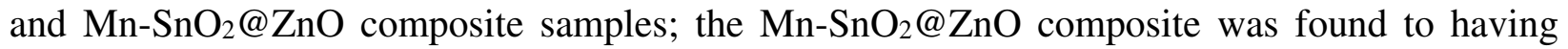
relatively smaller crystallites when compared to the other samples. The $\mathrm{Mn}$ and $\mathrm{Zn}$ ions 
minimize the growth rate and nucleation of the $\mathrm{SnO}_{2}$ structure. The lower crystallite size helps in increasing the surface area and it may also enhance the photocatalytic activities.

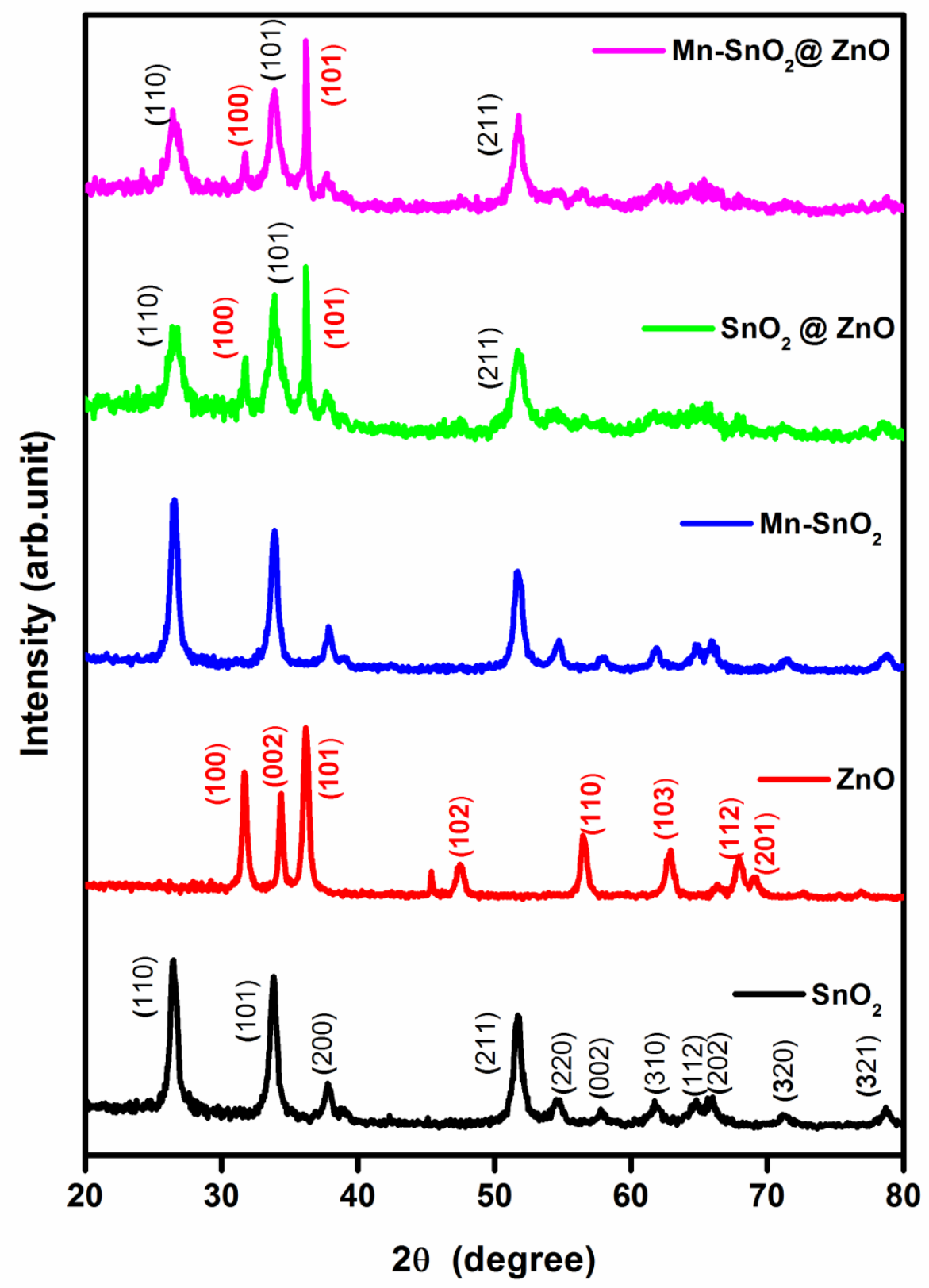

Figure 1 PXRD pattern of synthesized $\mathrm{SnO}_{2}, \mathrm{ZnO}, \mathrm{Mn}-\mathrm{SnO}_{2}, \mathrm{SnO}_{2} @ \mathrm{ZnO}$ and $\mathrm{Mn}-\mathrm{SnO}_{2} @ \mathrm{ZnO}$ composite samples.

Fourier transform infrared spectroscopy analysis 
Figure 2 depicts the Fourier transform infrared (FTIR) spectra of the synthesized $\mathrm{SnO}_{2}$, $\mathrm{Mn}-\mathrm{SnO}_{2}, \mathrm{ZnO}, \mathrm{SnO}_{2} @ \mathrm{ZnO}$ and $\mathrm{Mn}_{-} \mathrm{SnO}_{2} @ \mathrm{ZnO}$ composite samples. A strong peak appeared at $665 \mathrm{~cm}^{-1}$ and $558 \mathrm{~cm}^{-1}$ correspond to the $\mathrm{Sn}-\mathrm{O}-\mathrm{Sn}$ and $\mathrm{Sn}-\mathrm{O}$ stretching vibrations, respectively, and it confirms the formation of rutile, tetragonal structure of the $\mathrm{SnO}_{2}$ and $\mathrm{Mn}-\mathrm{SnO} 2$ samples. A small $\mathrm{ZnO}$ vibration peak observed at $461 \mathrm{~cm}^{-1}$ is related to $\mathrm{Zn}-\mathrm{O}$ stretching mode. In the $\mathrm{SnO}_{2} @ \mathrm{ZnO}$ and $\mathrm{Mn}-\mathrm{SnO}_{2} @ \mathrm{ZnO}$ composite samples, the FTIR spectra revealed both $\mathrm{Sn}-\mathrm{O}-\mathrm{Sn}$ stretching and $\mathrm{Zn}-\mathrm{O}$ stretching modes around $620 \mathrm{~cm}^{-1}$ and $488 \mathrm{~cm}^{-1}$ respectively [30,31]. In addition, the $\mathrm{OH}$ stretching and bending vibration modes observed around $\sim 3430 \mathrm{~cm}^{-1}$ and $\sim 1620 \mathrm{~cm}^{-1}$ which are due to the absorption of water molecules on the surface of the synthesized samples. The small absorption changes were observed in the composite samples due to the addition of $\mathrm{Mn}$ and $\mathrm{Zn}$ in $\mathrm{SnO}_{2}$ sites. The FTIR spectra also confirm the presence of $\mathrm{ZnO}$ and $\mathrm{SnO}_{2}$ elements which is in good agreement with the PXRD results.

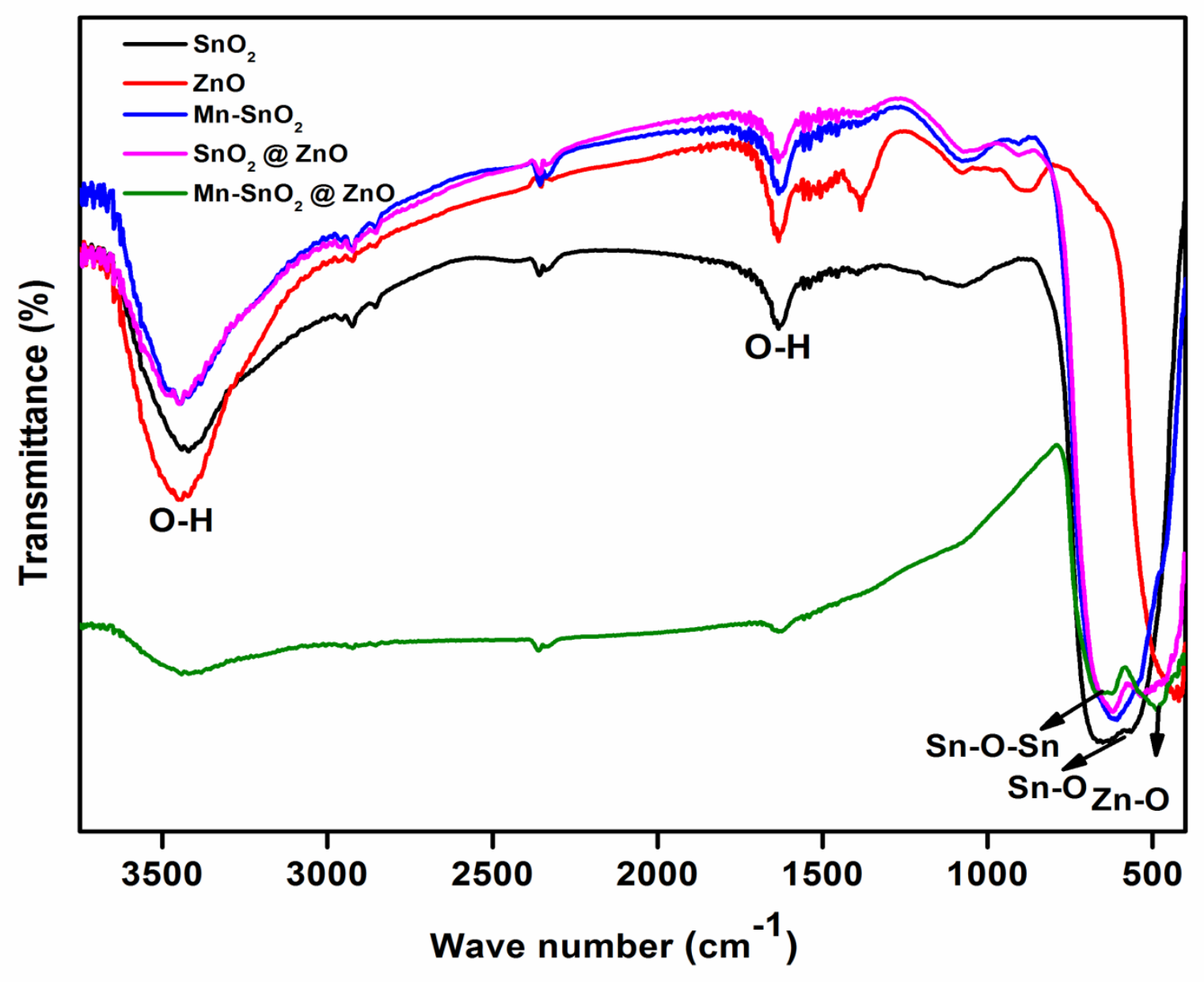


Figure 2 FTIR spectra of the synthesized $\mathrm{SnO}_{2}, \mathrm{Mn}-\mathrm{SnO}_{2}, \mathrm{ZnO}, \mathrm{SnO}_{2} @ \mathrm{ZnO}$ and Mn$\mathrm{SnO}_{2} @ \mathrm{ZnO}$ composites samples.

\section{UV-visible spectra analysis}

UV-Visible absorption properties of the synthesized $\mathrm{SnO}_{2}, \mathrm{Mn}-\mathrm{SnO}_{2}, \mathrm{ZnO}, \mathrm{SnO}_{2} @ \mathrm{ZnO}$ and $\mathrm{Mn}-\mathrm{SnO}_{2} @ \mathrm{ZnO}$ composite samples were analyzed in the range of 200-800 nm at room temperature and the absorption spectra are shown in figure 3 (A). The maximum absorption peaks were observed at $278 \mathrm{~nm}, 288 \mathrm{~nm}$ and $358 \mathrm{~nm}$ for the $\mathrm{SnO}_{2}, \mathrm{Mn}-\mathrm{SnO}_{2}$ and $\mathrm{ZnO}$ nanoparticles. Further, the maximum absorption peaks were slightly shifted in the higher wave length side (red shift) due to the formation of $\mathrm{SnO}_{2} @ \mathrm{ZnO}$ heterostructures and also the maximum absorption peak of $\mathrm{SnO}_{2} @ \mathrm{ZnO}$ and $\mathrm{Mn}_{-} \mathrm{SnO}_{2} @ \mathrm{ZnO}$ composite samples were appeared in between the absorption peaks corresponding to $\mathrm{SnO}_{2}$ and $\mathrm{ZnO}$. The absorption edges were found in between 390-460 nm for all the synthesized samples. In addition, the band gap energies of all the synthesized samples were estimated by using Tauc plots using the relation given below [11, 32]:

$$
\alpha h v=A\left(h v-E_{g}\right)^{n}
$$

where, $\alpha$ is the absorption coefficient, $v$ is the frequency, $h$ is the Plank's constant, $A$ is a constant, $E_{g}$ is the Energy gap and $n=1 / 2$ for the direct band gap of the semiconductors.

The estimated energy band gap values are 3.52, 3.32, 3.01, 3.12 and $2.77 \mathrm{eV}$ for the synthesized $\mathrm{SnO}_{2}, \mathrm{Mn}-\mathrm{SnO}_{2}, \mathrm{ZnO}, \mathrm{SnO}_{2} @ \mathrm{ZnO}$ and $\mathrm{Mn}-\mathrm{SnO}_{2} @ \mathrm{ZnO}$ composite samples, respectively and are shown in figure 3 (B). The $\mathrm{Mn}-\mathrm{SnO}_{2} @ \mathrm{ZnO}$ composite has a lower band gap values compared to all other synthesized samples, which may be due to the addition of Mn in $\mathrm{SnO}_{2}$ sites and $\mathrm{Zn}$ ions respectively. When adding the metals in $\mathrm{SnO}_{2}$, the peak position was moved to higher wavelength sides and it would help to enhance the strength of visible light absorption. The UV-visible spectra revealed the visible light absorption by the composite samples which induce enhanced photocatalytic efficiency of the composite samples. 

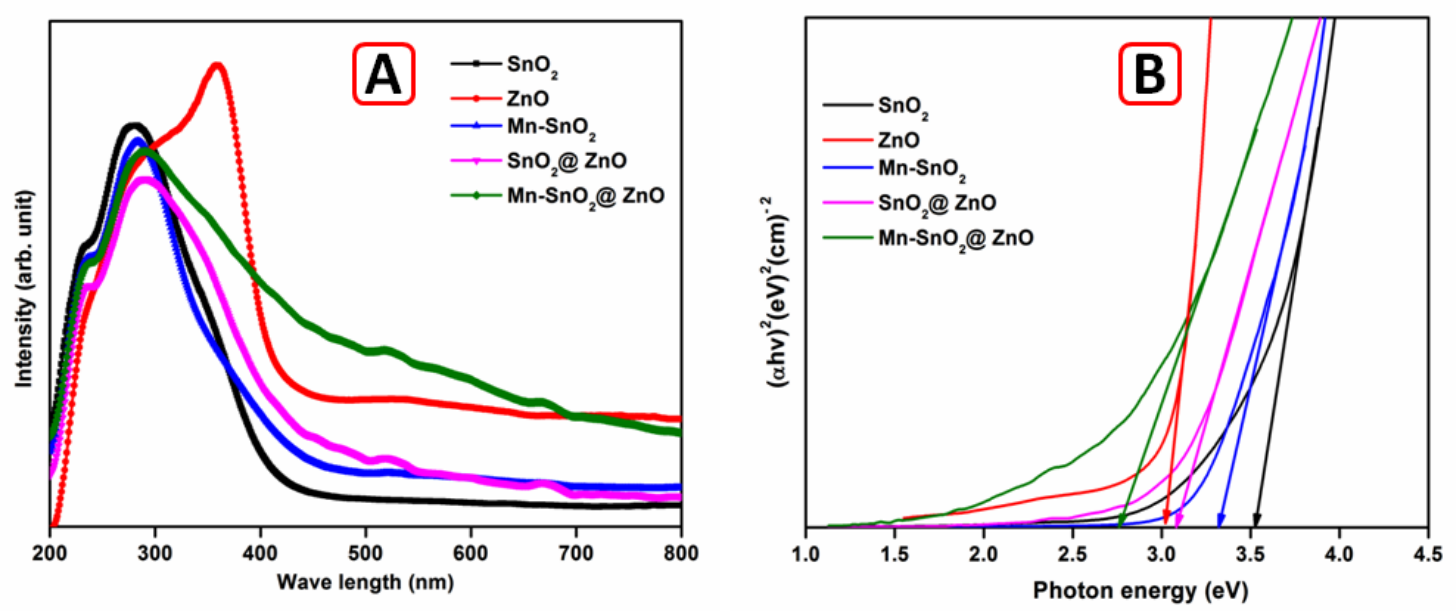

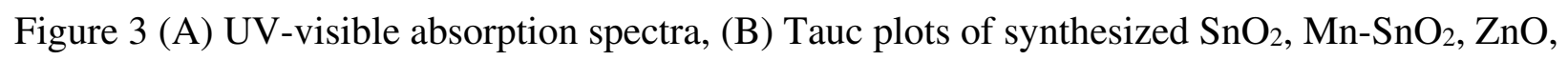
$\mathrm{SnO}_{2} @ \mathrm{ZnO}$ and $\mathrm{Mn}-\mathrm{SnO}_{2} @ \mathrm{ZnO}$ composite samples.

\section{Photoluminescence Analysis}

The photoluminescence (PL) is one of the versatile techniques used to determine the surface defects and oxygen vacancies of the prepared samples. Figure 4, depicts the photoluminescence spectra of the synthesized $\mathrm{SnO}_{2}, \mathrm{Mn}-\mathrm{SnO}_{2}, \mathrm{ZnO}, \mathrm{SnO}_{2} @ \mathrm{ZnO}$ and $\mathrm{Mn}$ $\mathrm{SnO}_{2} @ \mathrm{ZnO}$ composite samples and it was recorded using an excitation wavelength of $320 \mathrm{~nm}$. The pure $\mathrm{SnO}_{2}$ spectra revealed five emission peaks that are centered at $361 \mathrm{~nm}, 377 \mathrm{~nm}, 411$ $\mathrm{nm}, 437 \mathrm{~nm}$ and $489 \mathrm{~nm}$ respectively. In the UV region, the near band edge (NBE) emission peak observed at $361 \mathrm{~nm}$ and $377 \mathrm{~nm}$. The blue-violet and blue emission related peaks are observed at $411 \mathrm{~nm}$ and $437 \mathrm{~nm}$ and are due to the electron recombination with shallow level defects and surface defects of the $\mathrm{SnO}_{2}$ nanoparticles [12]. The pure $\mathrm{ZnO}$ shows four different emission peaks: (1) a sharp UV band emission peak centered at $390 \mathrm{~nm}$ which is related to the near band edge emission, (2) a violet band was observed at $409 \mathrm{~nm}$, (3) a low intensity peak appeared at $438 \mathrm{~nm}$ corresponds to a blue band, (4) a sharp bluish-green emission peak centered at $490 \mathrm{~nm}$ respectively [33]. When compared to pure and doped samples, the $\mathrm{SnO}_{2} @ \mathrm{ZnO}$ and 


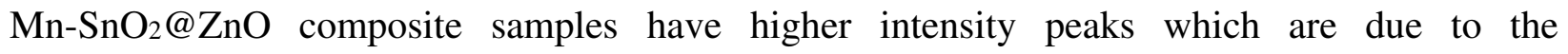
incorporation of $\mathrm{Mn}$ in the $\mathrm{SnO}_{2}$ sites and the addition $\mathrm{Zn}$ ions. This creates more oxygen vacancies and surface defects in the synthesized samples. The surface defects and the oxygen vacancies enhance the photocatalytic activities and the $\mathrm{Mn}^{-} \mathrm{SnO}_{2} @ \mathrm{ZnO}$ composite has a higher photocatalytic efficiency when compared with other samples.

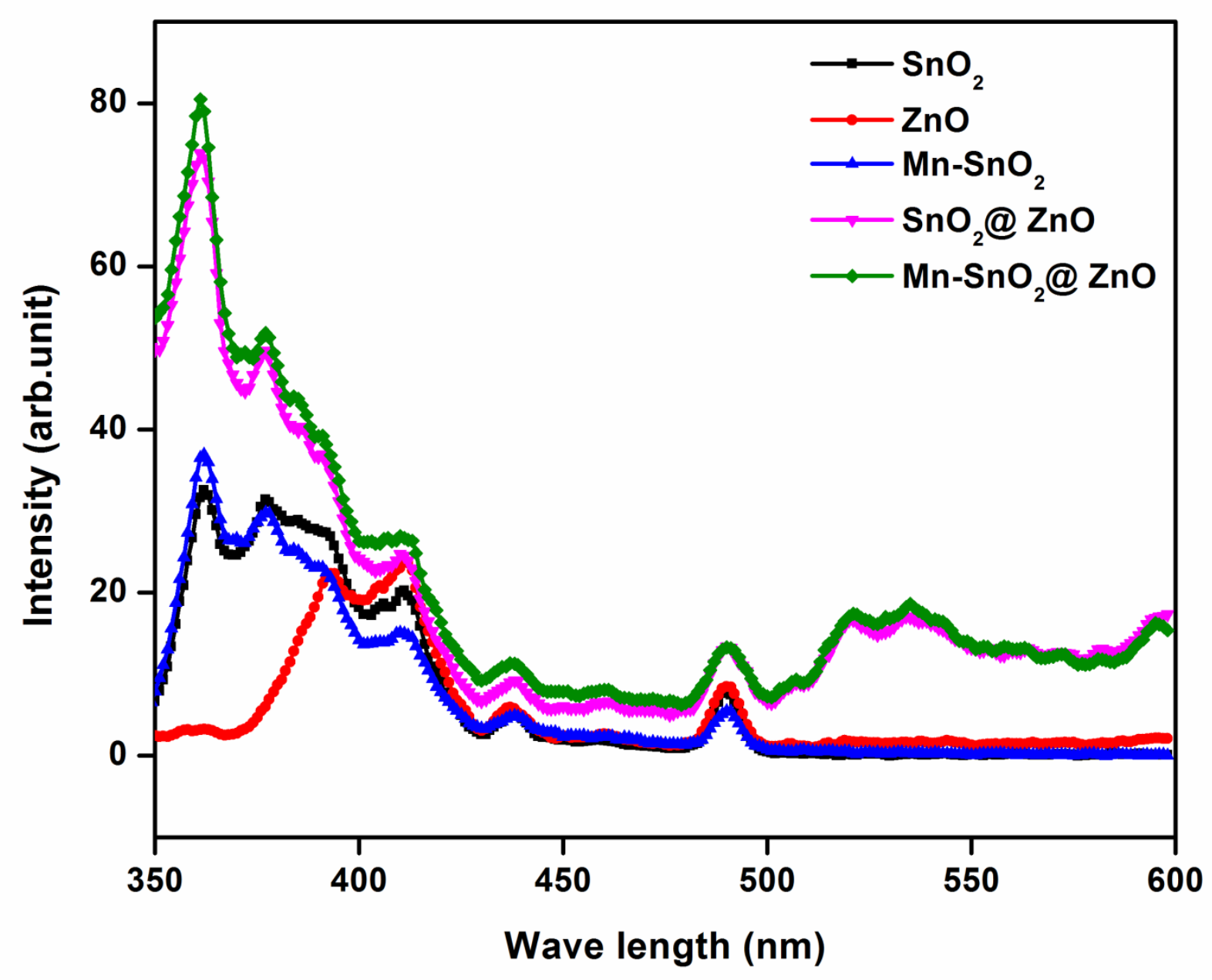

Figure 4 Photoluminescene spectra of synthesized $\mathrm{SnO}_{2}, \mathrm{Mn}-\mathrm{SnO}_{2}, \mathrm{ZnO}, \mathrm{SnO}_{2} @ \mathrm{ZnO}$ and $\mathrm{Mn}-$ $\mathrm{SnO}_{2} @ \mathrm{ZnO}$ composite samples.

Field Emission Scanning Electron Microscope analysis

The Field Emission Scanning Electron Microscope (FE-SEM) images of the synthesized $\mathrm{SnO}_{2}, \mathrm{ZnO}, \mathrm{Mn}-\mathrm{SnO}_{2}, \mathrm{SnO}_{2} @ \mathrm{ZnO}$ and $\mathrm{Mn}_{-} \mathrm{SnO}_{2} @ \mathrm{ZnO}$ composite samples are shown figure 5 (A-E). The FE-SEM images of the $\mathrm{SnO}_{2}, \mathrm{Mn}_{-} \mathrm{SnO}_{2}$ and $\mathrm{ZnO}$ show small spherical grains that are 
slightly agglomerated with one another as shown in figure $5(\mathrm{~A}-\mathrm{C})$. The size of the spherical grains are found to be around 16-45 $\mathrm{nm}$. When compared to the pure and doped samples, the $\mathrm{SnO}_{2} @ \mathrm{ZnO}$ and $\mathrm{Mn}-\mathrm{SnO}_{2} @ \mathrm{ZnO}$ composite samples show loosely bound spherical grain morphology as shown in figure $5(\mathrm{D}, \mathrm{E})$
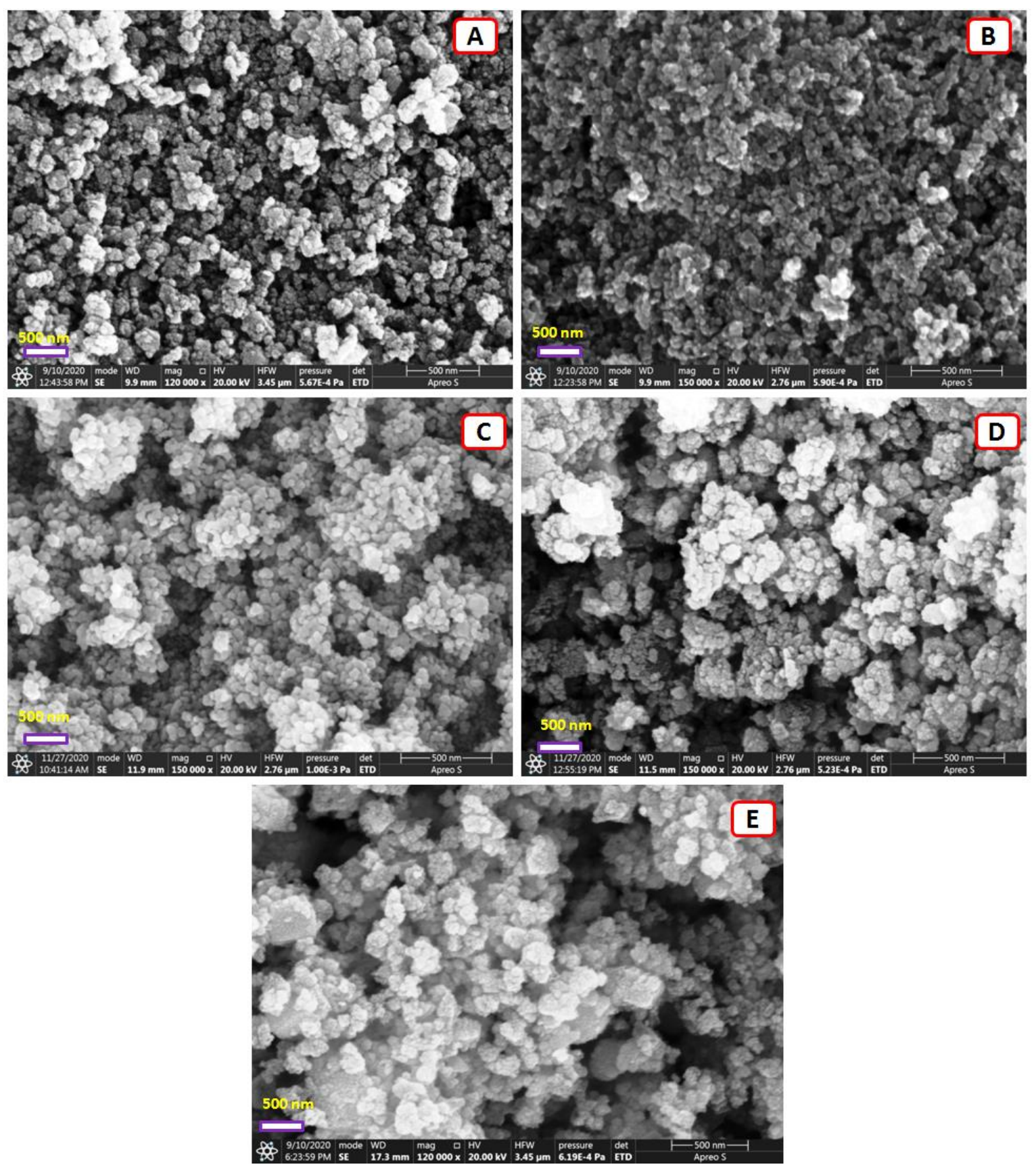

Figure 5 FE-SEM images of synthesized (A) $\mathrm{SnO}_{2}$, (B) $\mathrm{ZnO}$, (C) $\mathrm{Mn}_{-} \mathrm{SnO}_{2}$, (D) $\mathrm{SnO}_{2} @ \mathrm{ZnO}$ and (E) $\mathrm{Mn}_{-} \mathrm{SnO}_{2} @ \mathrm{ZnO}$ composite samples. 


\section{EDS and element mapping analyses}

Figure 6 displays the EDS spectra of the synthesized $\mathrm{SnO}_{2}, \mathrm{Mn}-\mathrm{SnO}_{2}, \mathrm{ZnO}, \mathrm{SnO}_{2} @ \mathrm{ZnO}$ and $\mathrm{Mn}-\mathrm{SnO}_{2} @ \mathrm{ZnO}$ composite samples. In the EDS spectra of the $\mathrm{SnO}_{2}$ and $\mathrm{ZnO}$, the presence of only $\mathrm{Sn}, \mathrm{O}$, and $\mathrm{Zn}, \mathrm{O}$ atoms are observed, respectively, as shown in figure 6(A,B). The Sn, $\mathrm{Zn}$ and $\mathrm{O}$ atoms are present in the $\mathrm{SnO}_{2} @ \mathrm{ZnO}$ and along with $\mathrm{Mn}$ in the $\mathrm{Mn}-\mathrm{SnO}_{2} @ \mathrm{ZnO}$ composites, respectively, as shown in figure $6(\mathrm{C}-\mathrm{E})$. No other impurity atoms were identified in the synthesized samples which affirm the purity of the synthesized materials. The obtained atomic percentage and weight percentage of the elements are inserted in the corresponding EDS spectra. 

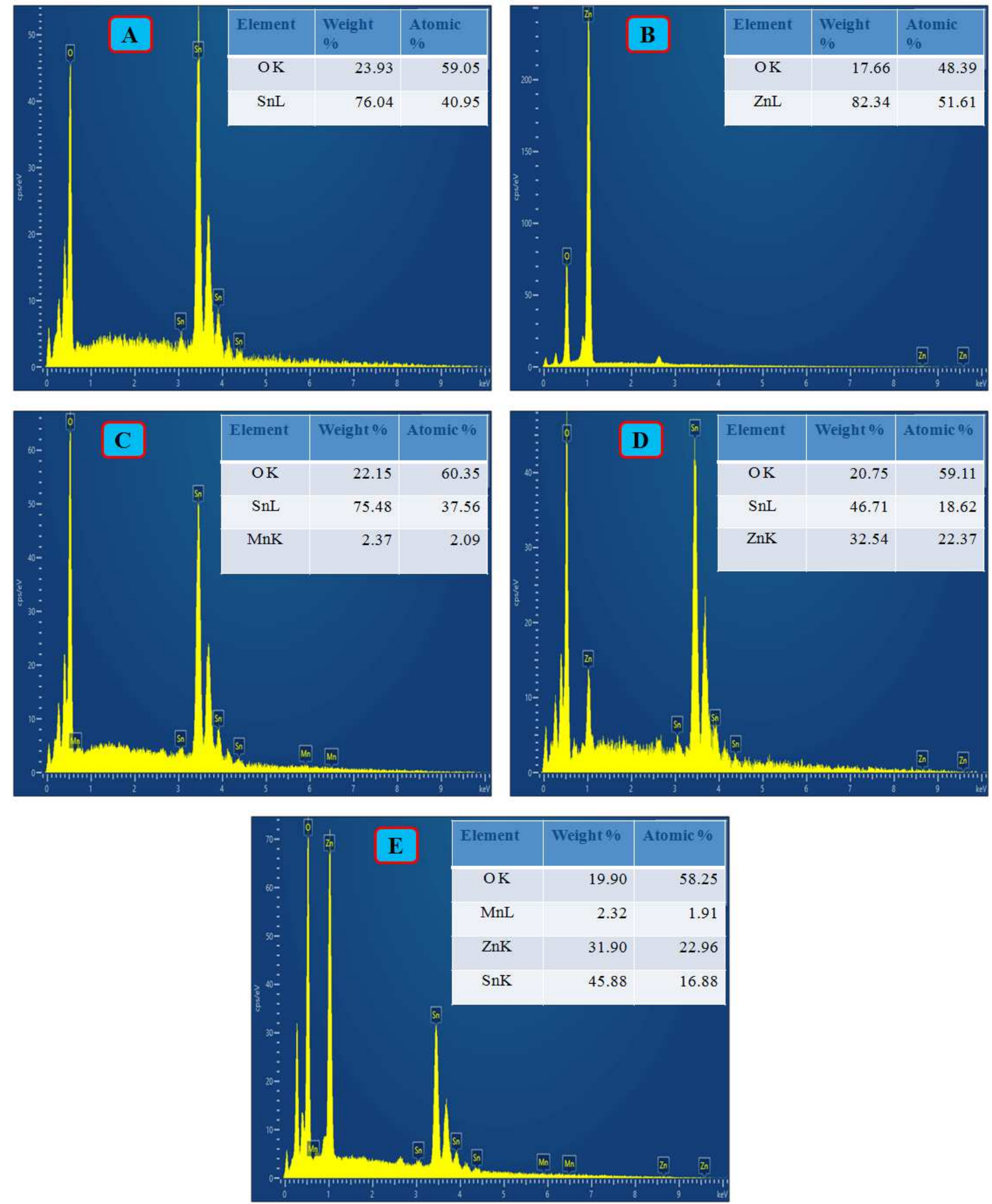

Figure 6 EDS spectra of the synthesized (A) $\mathrm{SnO}_{2}$, (B) $\mathrm{ZnO}$, (C) $\mathrm{Mn}_{-} \mathrm{SnO}_{2}$, (D) $\mathrm{SnO}_{2} @ \mathrm{ZnO}$ and (E) $\mathrm{Mn}_{-} \mathrm{SnO}_{2} @ \mathrm{ZnO}$ composite samples. 
The element mapping images of the synthesized samples are shown in figure 7 . The mapping images also confirm the purity of the samples. Moreover, the observed elements are appeared on the entire surface of the materials.

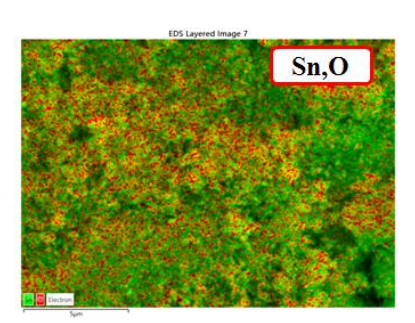

Zn $L \alpha 1,2$

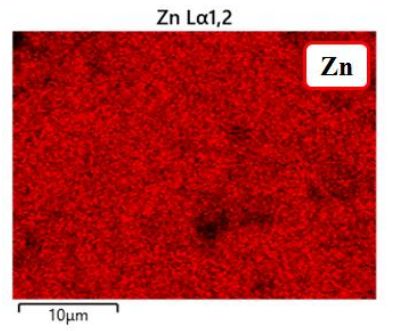

Mn L $\alpha 1,2$

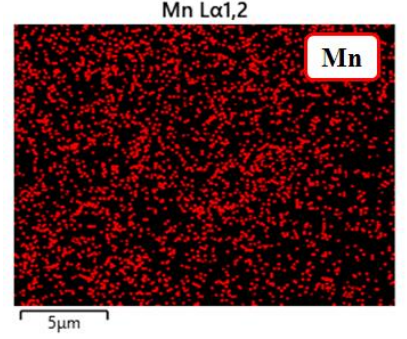

Zn L 1,2

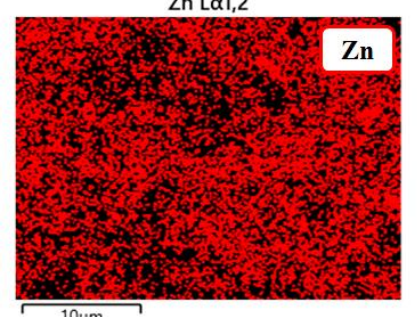

Sn $L \alpha 1$

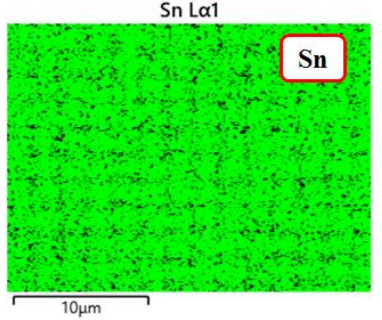

$\mathrm{O} K \alpha 1$

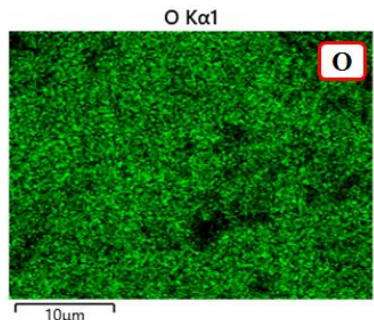

$\mathrm{O} K \alpha 1$

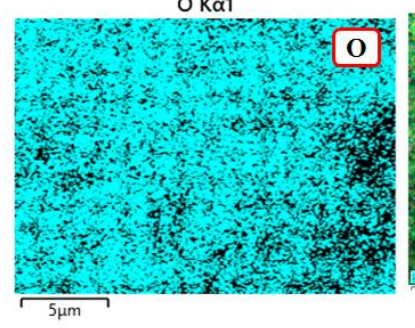

$\mathrm{O} K \alpha 1$

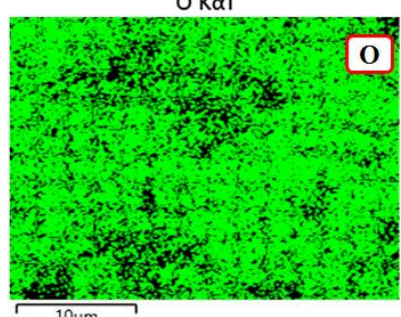

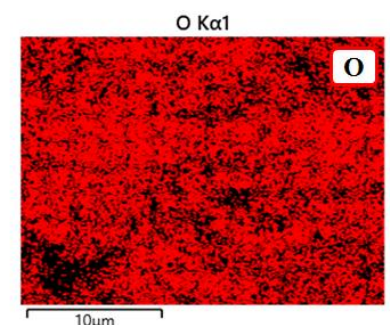

$10 \mu \mathrm{m}$
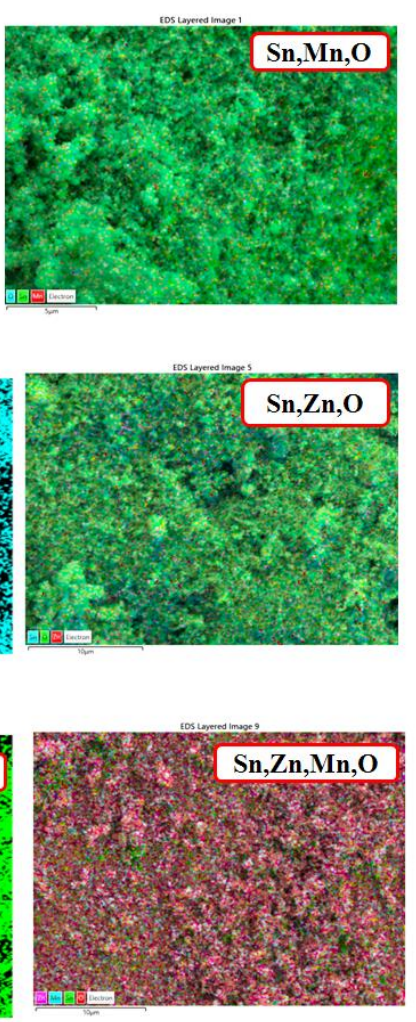

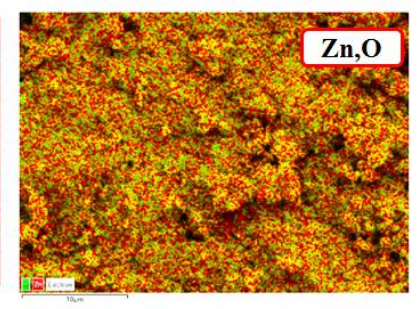

Sn La1

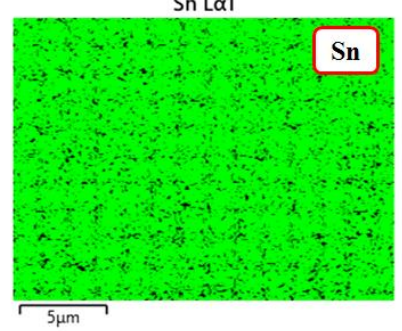

Sn $L \alpha 1$

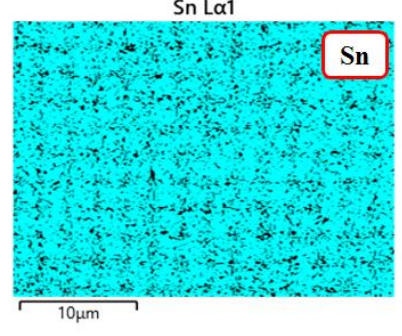

Sn L $\alpha 1$

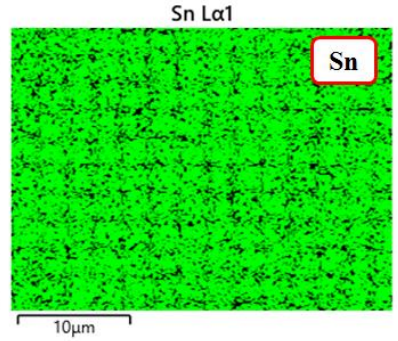

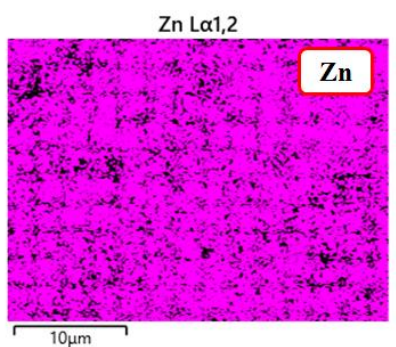
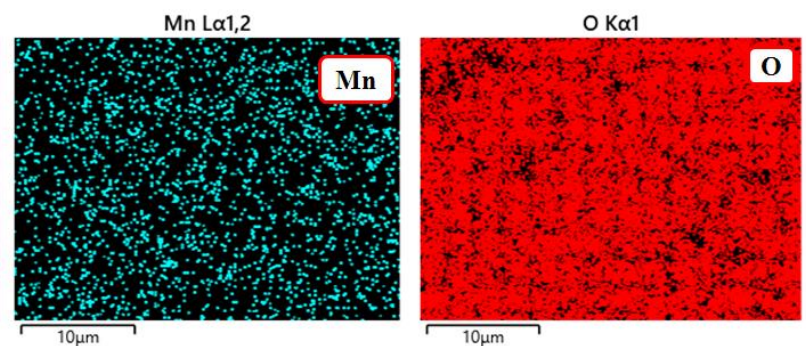

o

Figure 7 Element mapping of the synthesized $\mathrm{SnO} 2, \mathrm{ZnO}, \mathrm{Mn}-\mathrm{SnO}_{2}, \mathrm{SnO}_{2} @ \mathrm{ZnO}$ and Mn$\mathrm{SnO}_{2} @ \mathrm{ZnO}$ composite samples. 


\section{X-ray photoelectron spectroscopy analysis}

The X-ray photoelectron spectra (XPS) revealed the presence of binding energy peaks of Sn, $\mathrm{Zn}, \mathrm{O}$ and $\mathrm{Mn}$ for $\mathrm{SnO}_{2} @ \mathrm{ZnO}$ and $\mathrm{Mn}_{-} \mathrm{SnO}_{2} @ \mathrm{ZnO}$ composites and are displayed in figure 8 (A-E). As shown figure 8 (B), the two obvious peaks of Sn, Sn $3 d_{5 / 2}$ and $\mathrm{Sn} 3 d_{3 / 2}$ are seen at $485.3 \mathrm{eV}$ and $493.7 \mathrm{eV}$, respectively, which confirm the $\mathrm{Sn}^{4+}$ state of Sn [34]. The $\mathrm{Zn} 2 \mathrm{p}$ core level spectra is shown in figure $8(\mathrm{C})$ which contain two peaks positioned at $1020.5 \mathrm{eV}$ and $1043.8 \mathrm{eV}$ and these peaks correspond to $\mathrm{Zn} 2 p_{3 / 2}$ and $\mathrm{Zn} 2 p_{1 / 2}$, respectively. This confirms the $\mathrm{Zn}^{2+}$ state of $\mathrm{Zn}$ [35]. Furthermore, the wide scan spectra of Mn2p related peaks are exhibited at $642.7 \mathrm{eV}$ and $654.8 \mathrm{eV}$ which correspond to $\mathrm{Mn} 2 p_{3 / 2}$ and $\mathrm{Mn} 2 p_{1 / 2}$ respectively. The binding energy difference between the $\mathrm{Mn} 2 p_{3 / 2}$ and $\mathrm{Mn} 2 p_{1 / 2}$ is $11.5 \mathrm{eV}$ which confirms the $\mathrm{Mn}^{4+}$ state of $\mathrm{Mn}$ (see figure 8(D)) [36]. As shown in figure 8 (E), in the case of $\mathrm{SnO}_{2} @ \mathrm{ZnO}$ and $\mathrm{Mn}$ $\mathrm{SnO}_{2} @ \mathrm{ZnO}$ composites, the oxygen (O $\left.1 s\right)$ peak is positioned at $529.3 \mathrm{eV}$ which relates to the Sn-O-Sn lattice and the another peak at $530.6 \mathrm{eV}$ corresponds to the adsorbed $\mathrm{Ox}^{-}$ions $\left(\mathrm{O}^{-}\right.$and $\mathrm{O}^{2-}$ ions). No other impurity phase elements were determined in the synthesized composite samples and also the obtained results agree well with the PXRD and the EDS results. 

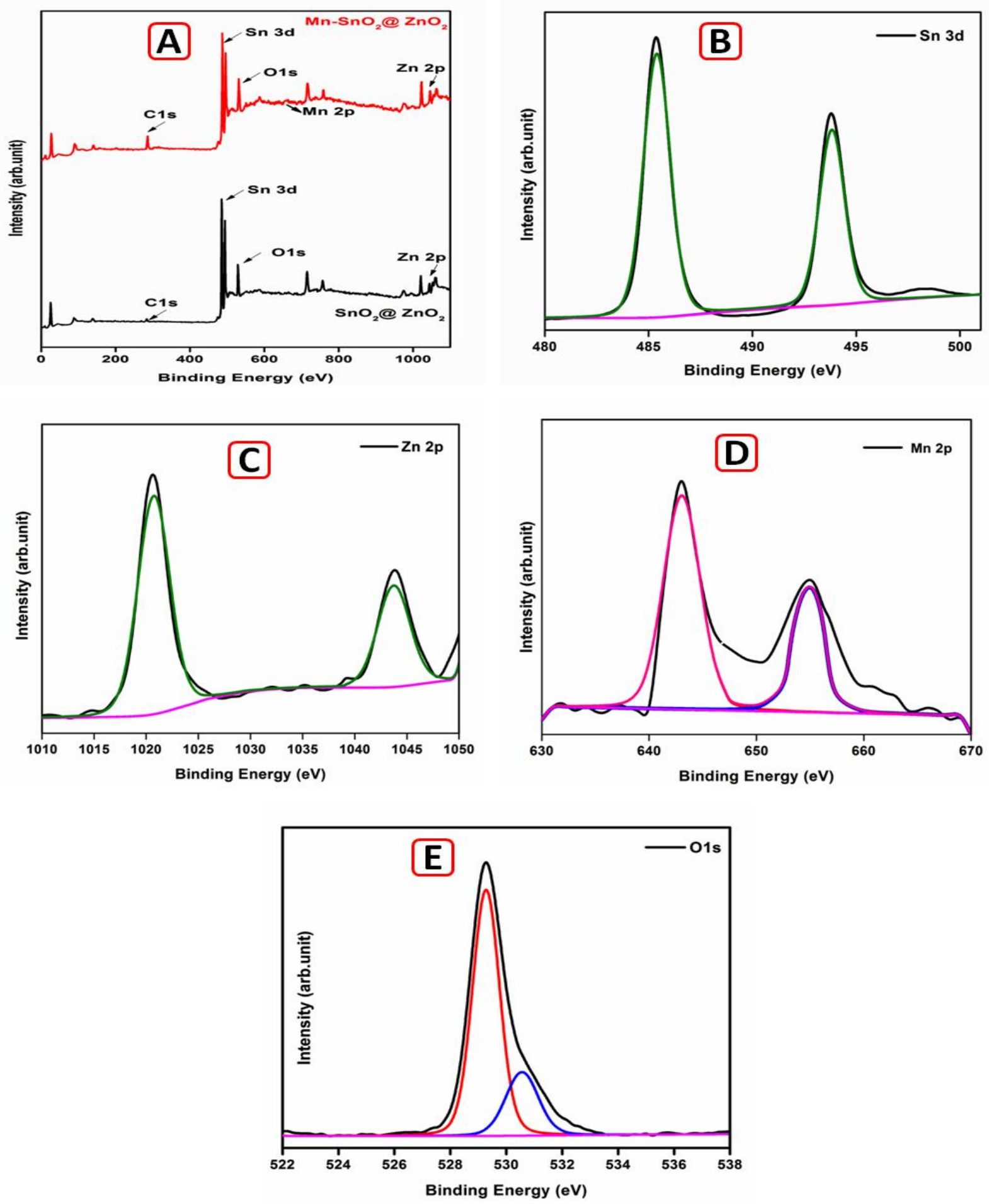

Figure 8 (A) Survey spectrum of $\mathrm{SnO}_{2} @ \mathrm{ZnO}$ and $\mathrm{Mn}-\mathrm{SnO}_{2} @ \mathrm{ZnO}$ samples, (B-E) Wide scan spectra of Sn3d, Zn2p, Mn2p and O1s levels, respectively. 


\section{Photocatalytic performance analysis}

The photocatalytic performance of the synthesized $\mathrm{SnO}_{2}, \mathrm{Mn}-\mathrm{SnO}_{2}, \mathrm{ZnO}, \mathrm{SnO}_{2} @ \mathrm{ZnO}$ and $\mathrm{Mn}-\mathrm{SnO}_{2} @ \mathrm{ZnO}$ composite samples were studied using methylene blue (MB) and rhodamine $\mathrm{B}(\mathrm{RhB})$ dye under visible light irradiation. In the absence of photocatalyst, negligible changes were observed in the $\mathrm{MB}$ and $\mathrm{RhB}$ dyes after $80 \mathrm{~min}$ of visible light irradiation. Up on the addition of the synthesized $\mathrm{SnO}_{2}, \mathrm{Mn}-\mathrm{SnO}_{2}, \mathrm{ZnO}, \mathrm{SnO}_{2} @ \mathrm{ZnO}$ and $\mathrm{Mn}-\mathrm{SnO}_{2} @ \mathrm{ZnO}$ photocatalysts, the major intensity peaks of $\mathrm{MB}$ and $\mathrm{RhB}$ found at $664 \mathrm{~nm}$ and $554 \mathrm{~nm}$ gradually decreased with increasing irradiation time. Among the synthesized catalyst, the $\mathrm{Mn}-\mathrm{SnO}_{2} @ \mathrm{ZnO}$ catalyst almost degrades the entire $\mathrm{MB}$ and $\mathrm{RhB}$ dyes by $80 \mathrm{~min}$ of irradiation and the data are shown in figure $9(\mathrm{~A}, \mathrm{~B})$. The Photo-degradation efficiency was estimated by using following formula [37].

$$
\text { Photo-degradation efficiency, } \eta=\left(1-C / C_{0}\right) \times 100(\%)
$$

where, $C_{0}$ is the initial $\mathrm{MB}$ dye concentration and $C$ is the dye concentration after irradiation.

The values of degradation efficiency with various photo-catalysts are given in table 1 and the same is plotted in figure $9(\mathrm{C}, \mathrm{D})$, respectively. Overall, the $\mathrm{Mn}_{-} \mathrm{SnO}_{2} @ \mathrm{ZnO}$ catalyst has been found to exhibit higher degradation efficiency when compared to the $\mathrm{SnO}_{2}, \mathrm{Mn}-\mathrm{SnO}_{2}, \mathrm{ZnO}$ and $\mathrm{SnO}_{2} @ \mathrm{ZnO}$ catalysts for the $\mathrm{MB}$ and $\mathrm{RhB}$ dyes. 

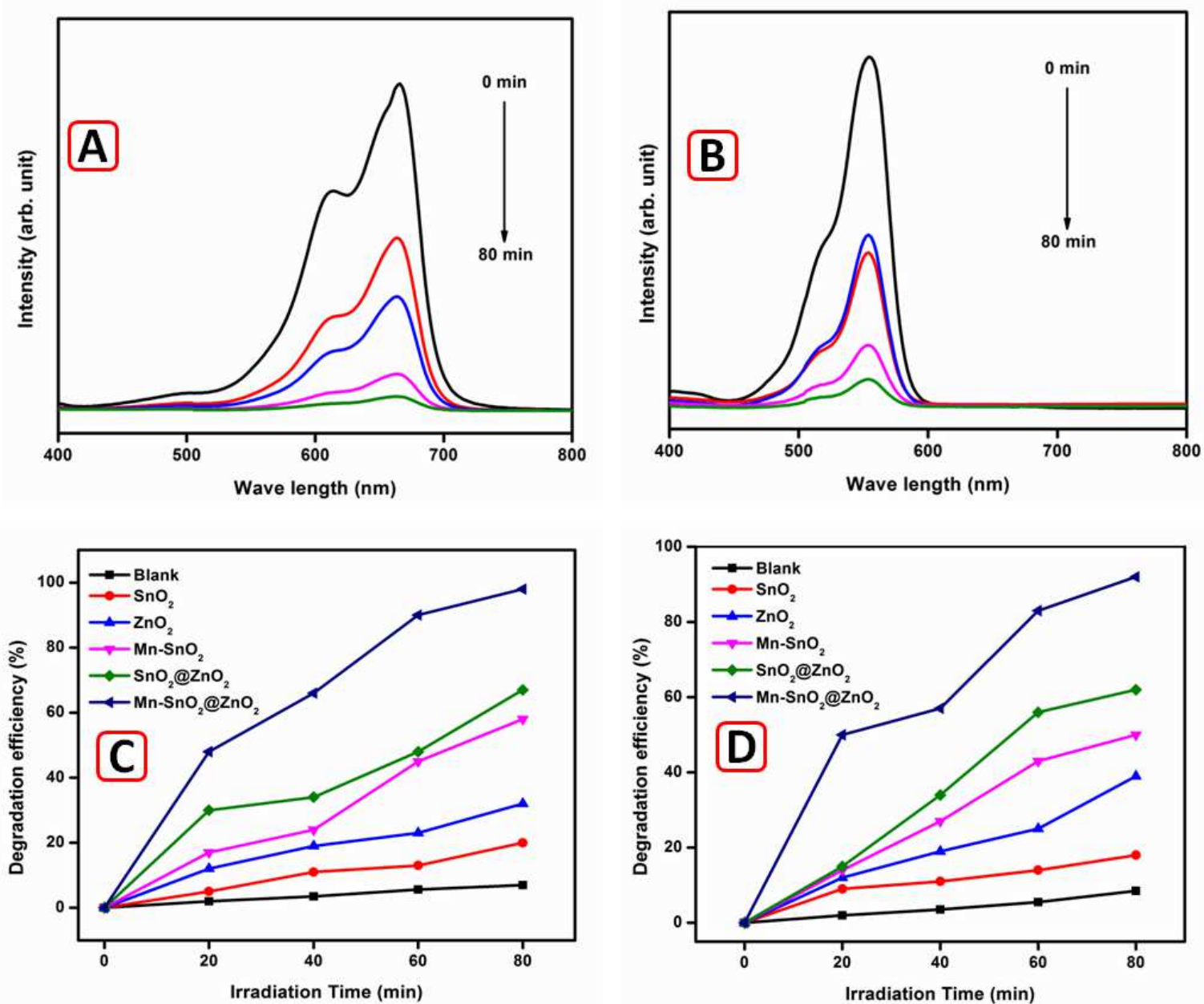

Figure $9(\mathrm{~A}, \mathrm{~B})$ The changes in the absorption peaks of $\mathrm{MB}$ and $\mathrm{RhB}$ dyes for $\mathrm{Mn}-\mathrm{SnO}_{2} @ \mathrm{ZnO}$ catalysts with different irradiation time, (C, D) Photo degradation efficiency of blank, $\mathrm{SnO}_{2}$, $\mathrm{ZnO}, \mathrm{Mn}-\mathrm{SnO}_{2}, \mathrm{SnO}_{2} @ \mathrm{ZnO}$ and $\mathrm{Mn}-\mathrm{SnO}_{2} @ \mathrm{ZnO}$ catalysts using $\mathrm{MB}$ and $\mathrm{RhB}$ dyes.

The degradation concentration ratio $\left(C / C_{0}\right)$ was calculated for all the synthesized samples and the data is shown in figure $10(\mathrm{~A}, \mathrm{~B})$. The $\mathrm{Mn}-\mathrm{SnO}_{2} @ \mathrm{ZnO}$ sample was found to exhibit higher $C / C_{0}$ when compared to the other photo-catalysts. The rate constant values of the prepared materials were calculated by Langmuir-Hinshelwood model using the following relation:

$$
\ln \left(C_{0} / C_{t}\right)=k t
$$

where $C_{0}$ is the initial concentration of dye, $C_{t}$ is the dye concentration after irradiation for a time period, $t$ and $k$ is the rate constant. 
Table 1, The efficiency, rate constant, degradation concentration for the prepared catalyst

\begin{tabular}{|c|c|c|c|c|c|c|}
\hline \multirow[t]{2}{*}{ Photo-catalyst } & \multicolumn{2}{|c|}{ Efficiency (\%) } & \multicolumn{2}{|c|}{$\begin{array}{c}\text { Rate Constant } \\
\left(\mathbf{m i n}^{-1}\right)\end{array}$} & \multicolumn{2}{|c|}{$\begin{array}{l}\text { Degradation } \\
\text { Concentration }\end{array}$} \\
\hline & MB & RhB & MB & RhB & MB & RhB \\
\hline $\begin{array}{l}\text { Blank (Without } \\
\text { catalyst) }\end{array}$ & 7 & 8.5 & 0.006 & 0.004 & 0.93 & 0.91 \\
\hline $\mathrm{SnO}_{2}$ & 20 & 18 & 0.011 & 0.015 & 0.80 & 0.82 \\
\hline ZnO & 32 & 39 & 0.013 & 0.018 & 0.68 & 0.61 \\
\hline${\mathrm{Mn}-\mathrm{SnO}_{2}}_{2}$ & 58 & 50 & 0.030 & 0.027 & 0.42 & 0.50 \\
\hline $\mathrm{SnO}_{2} @ \mathrm{ZnO}$ & 67 & 62 & 0.044 & 0.030 & 0.33 & 0.38 \\
\hline $\mathrm{Mn}-\mathrm{SnO}_{2} @ \mathrm{ZnO}$ & 98 & 92 & 0.077 & 0.054 & 0.03 & 0.08 \\
\hline
\end{tabular}

The rate constant values gradually increased with increasing irradiation time for both MB and $\mathrm{RhB}$ dyes. When rate constant values of all the prepared catalyst are compared, the Mn$\mathrm{SnO}_{2} @ \mathrm{ZnO}$ catalyst was found to have a high rate constant. The corresponding variations of the rate constant $v s$ irradiation time is shown in figure $10(\mathrm{C}, \mathrm{D})$ and also tabulated in table 1 . The lower band gap, large surface area, the formation of heterojunction of $\mathrm{Mn}_{-} \mathrm{SnO}_{2}$ and $\mathrm{ZnO}$ helped to increase the separation of photo-generated electrons and holes from recombination process which promoted the photo-catalytic reaction and efficiency of the catalyst. 

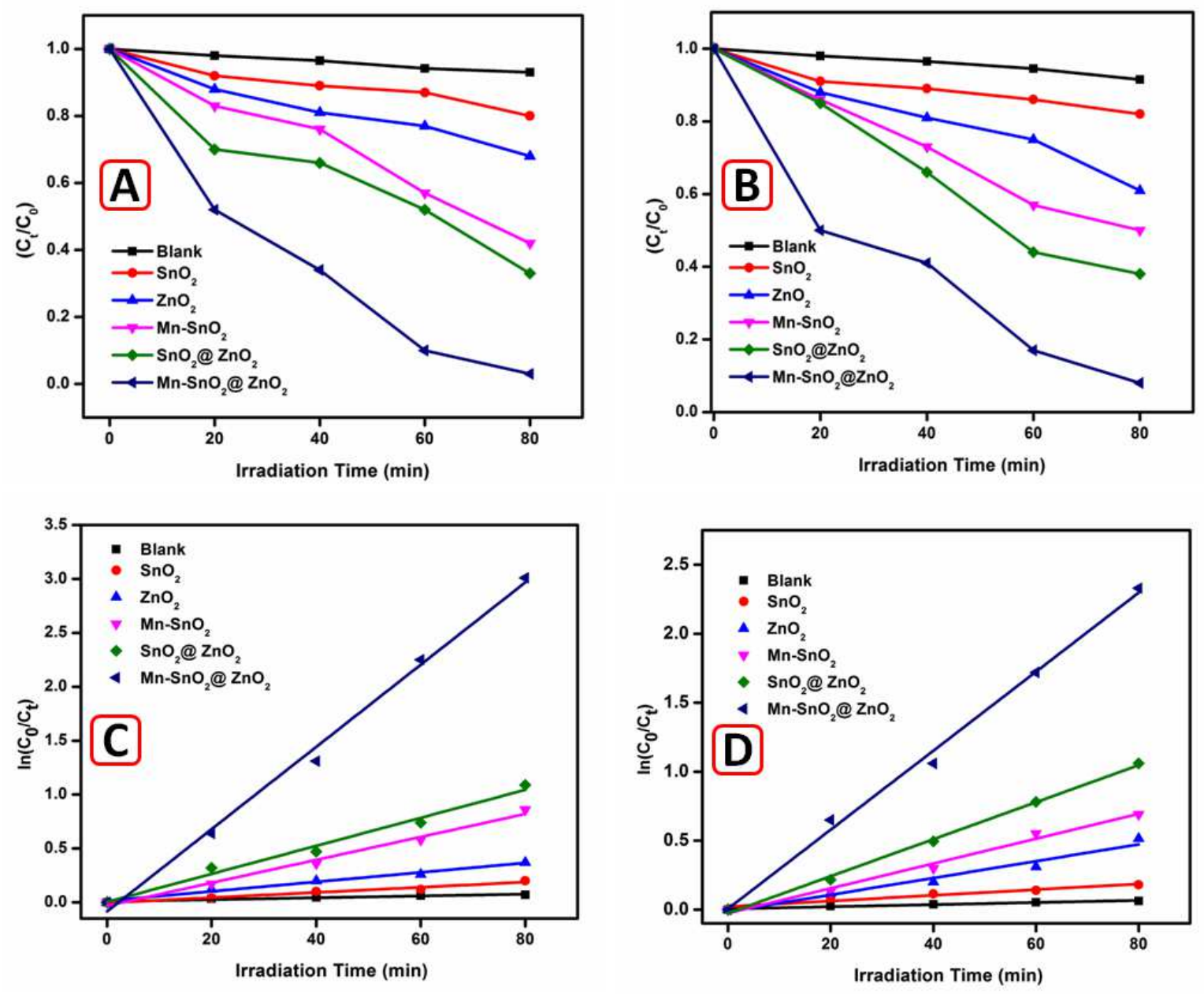

Figure 10 (A,B) Degradation concentration ratio, (C, D) Kinetic study of the blank (no catalyst), $\mathrm{SnO}_{2}, \mathrm{Mn}_{-} \mathrm{SnO}_{2}, \mathrm{ZnO}, \mathrm{SnO}_{2} @ \mathrm{ZnO}$ and $\mathrm{Mn}_{-} \mathrm{SnO}_{2} @ \mathrm{ZnO}$ catalysts using $\mathrm{MB}$ and $\mathrm{RhB}$ dyes with different irradiation time.

The stability test is an important phenomenon which determines the reusability of the prepared material. The $\mathrm{Mn}-\mathrm{SnO}_{2} @ \mathrm{ZnO}$ photo-catalyst was used to conduct the recycling performance analysis against $\mathrm{MB}$ and $\mathrm{RhB}$ dyes under visible light irradiation. After three consecutive recycles, the degradation efficiencies of $\mathrm{MB}$ and $\mathrm{RhB}$ dyes reached 95 and $90 \%$ which is shown in figure $11(\mathrm{~A}, \mathrm{~B})$. After recycles, the $\mathrm{Mn}-\mathrm{SnO}_{2} @ \mathrm{ZnO}$ photo-catalyst was examined using XRD analysis. The XRD pattern of the recycled catalyst is seen to be similar to that of the unused one and is shown in figure 11(C). The recycle performance analysis revealed 
that the $\mathrm{Mn}-\mathrm{SnO}_{2} @ \mathrm{ZnO}$ catalyst has excellent degradation efficiency and it can be used as a photo-catalyst for industries' waste water treatments.
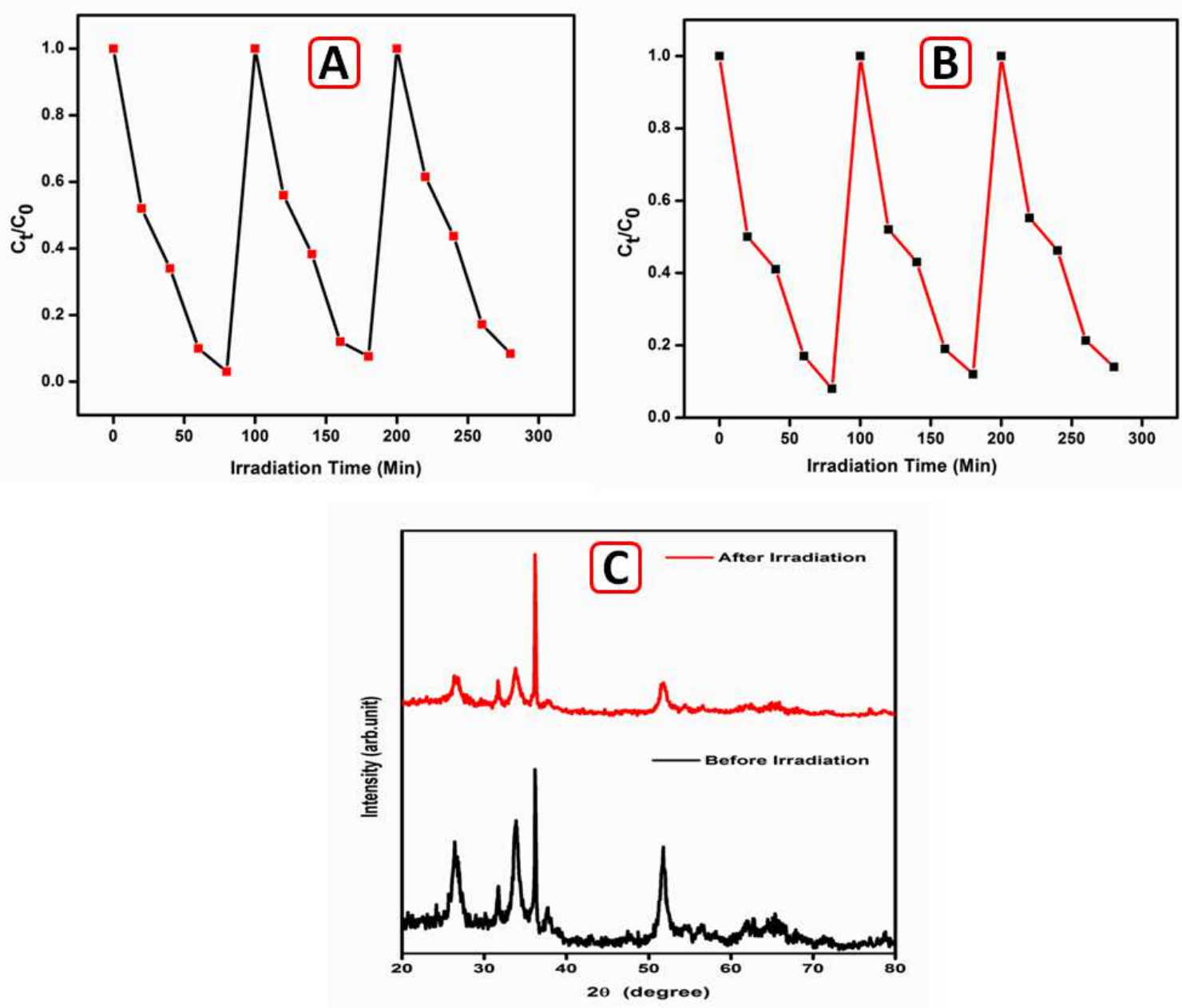

Figure 11(A,B) Mn-SnO $2 @ \mathrm{ZnO}$ catalyst stability against $\mathrm{MB}$ and $\mathrm{RhB}$ dyes upon cyclic irradiation of 80 min duration, (B) The XRD patterns of $\mathrm{Mn}-\mathrm{SnO}_{2} @ \mathrm{ZnO}$ photo-catalyst before and after the photocatalytic reaction.

\section{Photocatalytic mechanism}

The photo-catalytic performances were analyzed for the $\mathrm{SnO}_{2}, \mathrm{Mn}-\mathrm{SnO}_{2}, \mathrm{ZnO}$, $\mathrm{SnO}_{2} @ \mathrm{ZnO}$ and $\mathrm{Mn}-\mathrm{SnO}_{2} @ \mathrm{ZnO}$ catalysts under visible light irradiation using $\mathrm{MB}$ and $\mathrm{RhB}$ organic dyes. Among the catalyst, the $\mathrm{Mn}-\mathrm{SnO}_{2} @ \mathrm{ZnO}$ was found to exhibit higher degradation efficiency for both the MB and RhB dyes. The enhanced photocatalytic activity was observed for the $\mathrm{Mn}-\mathrm{SnO}_{2} @ \mathrm{ZnO}$ catalyst due to the coupling of semiconductors with different band gaps 
which favours for the electron hole separation. Due to more electron hole separation, the enriched photocatalytic activity was identified for the $\mathrm{Mn}-\mathrm{SnO}_{2} @ \mathrm{ZnO}$ which is based on the band alignment. Further, the semiconductors band edge potential level plays a vital role in determining the flow of photo-excited charge carriers. The band edge potentials of conduction and valance band of $\mathrm{SnO}_{2}, \mathrm{Mn}-\mathrm{SnO}_{2}$ and $\mathrm{ZnO}$ were calculated by using the below relations:

$$
\begin{gathered}
E_{V B}=X-E_{e}+0.5 E_{g} \\
E_{C B}=E_{V B}-E_{g}
\end{gathered}
$$

where, $E_{V B}$ is the valence band edge potential, $E_{C B}$ is the conduction band edge potential, $X$ is the electro-negativity of the semiconductors $\mathrm{SnO}_{2}$ and $\mathrm{ZnO}(6.0$ and $5.79 \mathrm{eV}), E_{e}$ is the energy of

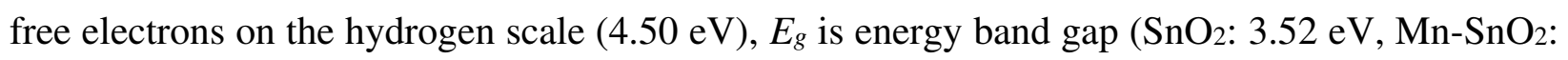
$3.32 \mathrm{eV}$ and $\mathrm{ZnO}: 3.01 \mathrm{eV})$. The valance band edge potential $\left(E_{V B}\right)$ was found to be $3.26 \mathrm{eV}, 3.16$ $\mathrm{eV}$ and $2.795 \mathrm{eV}$ and conduction band edge potential $\left(E_{C B}\right)$ was found at $-0.26 \mathrm{eV},-0.16 \mathrm{eV}$ and $-0.21 \mathrm{eV}$ for the $\mathrm{SnO}_{2}, \mathrm{Mn}-\mathrm{SnO}_{2}$ and $\mathrm{ZnO}$ catalysts, respectively. Figure 12(A) shows the charge transfer schematic mechanism of the prepared $\mathrm{Mn}-\mathrm{SnO}_{2} @ \mathrm{ZnO}$ catalyst. When visible light pass through the $\mathrm{Mn}-\mathrm{SnO}_{2} @ \mathrm{ZnO}$ hetero-structure, the electrons from the valence band are excited to the conduction band of the $\mathrm{Mn}-\mathrm{SnO}_{2}$ and $\mathrm{ZnO}$ and simultaneously holes are generated in the valance band. The photo generated electrons moved from higher energetically $\mathrm{ZnO} \mathrm{CB}$ edge to lower $\mathrm{CB}$ edge of $\mathrm{Mn}-\mathrm{SnO}_{2}$ and holes are moved in the opposite side due to the appropriate valance band position. Thus, photo-generated electrons and holes were vertically moved to Mn$\mathrm{SnO}_{2}$ and $\mathrm{ZnO}$ which gives higher charge separation and lower charge recombination. The higher charge separation also helped to enhance the charge carrier life time and also enrich the interfacial charge transfer to adsorbed surface of the organic pollutants which helped to enhance the photocatalytic performance of the $\mathrm{Mn}_{-} \mathrm{SnO}_{2} @ \mathrm{ZnO}$ composite.

A possible reaction mechanism is proposed as follows:

$$
\begin{aligned}
\mathrm{Mn}-\mathrm{SnO}_{2}+h v \rightarrow \mathrm{h}^{+}(\mathrm{ZnO})+\mathrm{e}^{-}\left(\mathrm{Mn}-\mathrm{SnO}_{2}\right) \\
\mathrm{O}_{2}+\mathrm{e}^{-} \rightarrow \cdot \mathrm{O}_{2}^{-} \\
\cdot \mathrm{O}_{2}^{-}+\mathrm{H}_{2} \mathrm{O} \rightarrow \mathrm{HO}_{2}^{-}+\mathrm{OH}^{-} \\
\mathrm{HO}_{2}^{--}+\mathrm{H}_{2} \mathrm{O} \rightarrow \mathrm{H}_{2} \mathrm{O}_{2}+\mathrm{OH}^{+} \\
\mathrm{H}_{2} \mathrm{O}_{2} \rightarrow 2 \mathrm{OH}^{.}
\end{aligned}
$$




$$
\begin{gathered}
\mathrm{h}^{+}+\mathrm{OH}^{-} \rightarrow \cdot \mathrm{OH} \\
\cdot \mathrm{OH}+\mathrm{MB} \rightarrow \text { Degradation Products }
\end{gathered}
$$

The electron in the conduction band of $\mathrm{SnO}_{2}$ reacts with oxygen adsorbed on the surface of $\mathrm{SnO}_{2}$ to generate superoxide radials anion $\left(\cdot \mathrm{O}_{2}^{-}\right)$. These $\cdot \mathrm{O}_{2}^{-}$radical further react with $\mathrm{H}_{2} \mathrm{O}$ to produce the $\cdot \mathrm{OH}$ radical. Simultaneously, holes $\left(\mathrm{h}^{+}\right)$migrated to $\mathrm{ZnO}$ react with $\mathrm{H}_{2} \mathrm{O}$ to produce hydroxyl $(\cdot \mathrm{OH})$ radical spices and the radicals degrade the $\mathrm{MB}$ and $\mathrm{RhB}$ dyes with degradation products of $\mathrm{CO}_{2}$ and water [38]. The trapping experiment was conducted by using benzoquinone (BQ), ethylenediamine tetra acetic acid disodium (EDTA), and isopropanol (IPA) as an $\mathrm{O}^{2-}, \mathrm{h}^{+}$ and $\cdot \mathrm{OH}$ radical scavengers respectively.
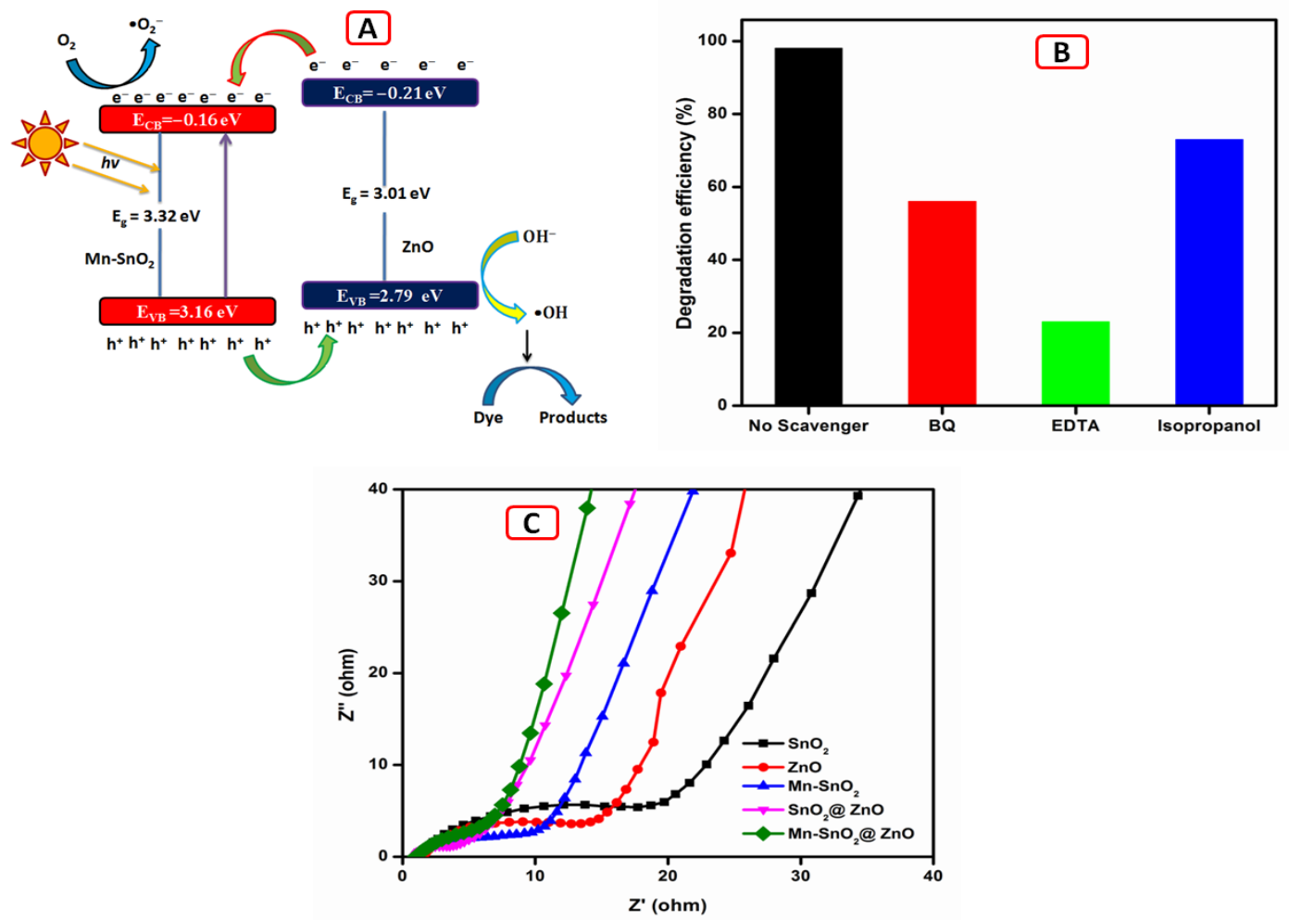

Figure 12 (A) Schematic diagram of the catalytic mechanism of $\mathrm{Mn}-\mathrm{SnO}_{2} @ \mathrm{ZnO}$ photo-catalyst, (B) Trapping experiment for the $\mathrm{Mn}-\mathrm{SnO}_{2} @ \mathrm{ZnO}$ photo-catalyst using MB dye, (C) EIS spectra of $\mathrm{SnO}_{2}, \mathrm{ZnO}, \mathrm{Mn}-\mathrm{SnO}_{2}, \mathrm{SnO}_{2} @ \mathrm{ZnO}$ and $\mathrm{Mn}-\mathrm{SnO}_{2} @ \mathrm{ZnO}$ samples.

The scavenger experiment results are shown in figure 12 (B). The result clearly revealed that BQ, EDTA, IPA reduce the photo-degradation efficiency under the visible light irradiation 
and also it confirms the superoxide and hydroxyl radicals are the important reactive species of the dye degradation process under the visible light irradiation. Apart from this, the EIS spectra also confirm the charge transfer and the recombination rate between the holes and photogenerated electrons. The EIS spectra of all the synthesized samples are shown in figure 12(C). The $\mathrm{Mn}_{-} \mathrm{SnO}_{2} @ \mathrm{ZnO}$ composite has lower solution and charge transfer resistances compared to other catalysts. The charge transfer resistance was found to be $19.7 \Omega, 15.6 \Omega, 10.7 \Omega, 6.2 \Omega$ and

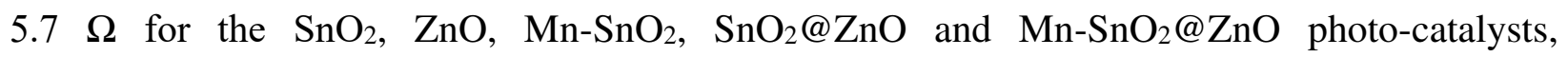
respectively. The EIS spectra confirm that the $\mathrm{Mn}-\mathrm{SnO}_{2} @ \mathrm{ZnO}$ has a higher charge transfer and lower recombination rates which helps to enhance the photocatalytic activity under the visible light irradiation.

\section{Conclusion}

In summary, we successfully synthesized $\mathrm{Mn}-\mathrm{SnO}_{2} @ \mathrm{ZnO}$ composite by using a simple chemical co-precipitation method. The structural, optical, morphology, purity, binding energy characteristics and the photocatalytic performances were analyzed for the synthesized samples. The $\mathrm{Mn}-\mathrm{SnO}_{2} @ \mathrm{ZnO}$ heterostructure was found to exhibit higher degradation efficiency when compared to pure $\mathrm{SnO}_{2}$ and $\mathrm{ZnO}$ samples using $\mathrm{MB}$ and $\mathrm{RhB}$ dyes under visible light irradiation. This is due to the separation of photo-generated electrons and holes and also due to higher charge transfer developed at the interface of the $\mathrm{Mn}-\mathrm{SnO}_{2} @ \mathrm{ZnO}$. From a detailed photo-catalytic performance analysis, the $\mathrm{Mn}_{-} \mathrm{SnO}_{2} @ \mathrm{ZnO}$ heterostructure has been found as a suitable material for waste water treatment as well as to remove the undesired organic compounds from the environment.

\section{Acknowledgements}

S.Asaithambi gratefully acknowledges RUSA 2.0 for awarding Ph.D. fellowship (F.No.Alu/RUSA/Ph.D Fellowships/2019) and G. Ravi greatly acknowledges the DST-SERB (File No. EMR/2017/001999), UGC-SAP (F.530/18/DRS-III/2015), DST-FIST (SR/FST/PSI202/2015), DST-PURSE (SR/PURSE Phase 2/38 (G)) and RUSA 2.0 (24-51/2014) for financial support to carry out this research work.

\section{Compliance with ethical standards}

Conflict of interest The authors declare that they have no conflict of interest 


\section{References}

[1] M. Sabarinathan, S. Harish, J. Archana, M. Navaneethan, H. Ikeda, Y. Hayakawa, RSC Adv., $724754-24763$ (2017) .

[2] S. Sai Guru Srinivasan, B. Govardhanan, P. Aabel, M. Ashok, M.C. Santhosh Kumar, Solar Energy, 187 368-378 (2019).

[3] A.Fujishima, K. Honda, Nature, 23837 -38(1972).

[4] H. Park, H. I. Kim, G. H. Moon and W. Choi, Energy Environ. Sci., 9 411-433 (2016).

[5] P. Li, Y. Lan, Q. Zhang, Z. Zhao, T. Pullerits, K. Zheng and Y. Zhou, J. Phys. Chem. C., 120 9253-9262 (2016).

[6] S. Kumar, A. Baruah, S. Tonda, B. Kumar, V. Shanker and B. Sreedhar, Nanoscale, 6 48304842 (2014).

[7] J.C. Colmenares, R. Luque, J.M. Campelo, F. Colmenares, Z. Karpinski, A.A. Romero, Materials, 2 2228-2258 (2009).

[8] S.S.Wu, H.Q.Cao, S.F.Yin, X.W.Liu and X.R.Zhang, J.Phys.Chem.C, 113 17893- 17898 (2009).

[9] X. Chen, B. H. Zhou, S. L. Yang, H. S. Wu, Y. Wu, L. Wu, J. Pan and X. Xiong, RSC Adv., 5 68953- 68963 (2015).

[10] B. Babu, A. Kadam, R. Ravikumar, C. Byon, J. Alloys Compd., 703 330-336 (2017).

[11] B. Babu, A.N. Kadam, G. Thirumala Rao, Sang-Wha Lee, Chan Byond, Jaesool Shim, Journal of Luminescence, 195 (2018) 283-289.

[12] S.Asaithambi, R.Murugan, P.Sakthivel, M.Karuppaiah, S.Rajendran, G.Ravi, Journal of nanoscience and nanotechnology, 19 4438-4446 (2019). 
[13] S.Asaithambi, P.Sakthivel, M.Karuppaiah, R.Murugan, R.Yuvakkumar, G.Ravi, Journal of electronic materials, 48 2183-2194 (2019).

[14] W.B.H. Othmen, B. Sieber, C. Cordier, H. Elhouichet, A. Addad, B. Gelloz, M. Moreau, A. Barras, M. Ferid, R. Boukherroub, Mater. Res. Bull. 83 481-490 (2016).

[15] Q.J. Xiang, J.G. Yu, M. Jaroniec, Chem. Soc. Rev., 41782 -796 (2012).

[16] H. Xia, H. Zhuang, T. Zhang, D. Xiao, Mater. Lett. 62 1126-1128 (2008).

[17] HL.Xia, HS.Zhuang, T. Zhang, DC.Xiao, J Environ Sci., 19 1141-1145 (2007).

[18] S.H.Hwang, C.Kim, J.Jang, Catal. Commun., 12 1037-1041(2011).

[19] C. Zhu, Y. Li, Q. Su, B. Lu, J. Pan, J. Zhang, E. Xie, W. Lan, J Alloys Compd., 575 333338 (2013).

[20] H.R. Pouretedal, Z. Tofangsazi, M.H. Keshavarz, J. Alloys. Compd., 513 359- 364 (2012).

[21] A. Priyadharsan, V. Vasanthakumar, S. Karthikeyan, V. Raj, S. Shanavas, P.M. Anbarasan, J. Photochem. Photobiol., A., 346 32-45 (2017).

[22] M.A. Subhan, T. Ahmed, N. Uddin, M.A.K. Azad and K. Begum, Spectrochim. Acta, Part A., $136824-831$ (2015).

[23] P. Senthil Kumar, M. Selvakumar, S. Ganesh Babu, S. Induja, S. Karuthapandian, J. Alloy. Compd., 701 562-573 (2017).

[24] Jiaojiao Lin, Zhanzhou Luo, Jiaojiao Liu, Ping Li, Materials Science in Semiconductor Processing, 87 24-31 (2018).

[25] H. F. Moafi, M. A. Zanjanchi and A. F. Shojaie, Materials Chemistry and Physics, 139 (2013) 856-864.

[26] Z.M. Tian, S.L. Yuan, J.H. He, P. Li, S.Q. Zhang, C.H. Wang, Y.Q. Wang, S.Y. Yin, L. Liu, J. Alloy. Compd., 466 26-30 (2008).

[27] M. Batzill, U. Diebold, Prog. Surf. Sci., 79 47-154 (2005). 
[28] G.Vijayaprasath, R.Murugan, S.Asaithambi, G.Anandha Babu, P.Sakthivel, T.Mahalingam, Y.Hayakawa, G.Ravi, Appl. Phys. A, 122:122(2016).

[29] T. Shrividhya, G. Ravi, Y.Hayakawa, T.Mahalingam, J Mater Sci: Mater Electron., 25 3885-3894 (2014).

[30] S.Asaithambi, P.Sakthivel, M.Karuppaiah, Y.Hayakawa, A.Loganathan, G.Ravi, Applied Physics A, 126:265 (2020).

[31] G. Vijayaprasath, R. Murugan, S. Asaithambi, P. Sakthivel, T. Mahalingam, Y. Hayakawa, G. Ravi, Ceramics International, 42 2836-2845(2016).

[32] G. Vijayaprasath, R. Murugan, T. Mahalingam, Y. Hayakawa, G. Ravi, Journal of Alloys and Compounds, 649 275-284 (2015).

[33] G.Vijayaprasath, R.Murugan, Y.Hayakawa, G.Ravi, Journal of Luminescence, 178 375-383 (2016).

[34] K. Mallikarjuna, Gazi A.K.M. Rafiqul Bari, S.V.Prabhakar Vattikuti, Haekyoung Kim, , International journal of hydrogen energy, 45 32789-32796 (2020).

[35] X.J Wang, W.Wang, Y.L.Liu, Sens. Actuators, B., 16839 -45 (2012).

[36] Q. Li, G. Li, C. Fu, D. Luo, J. Fan, D. Xie, L. Li, J.Mater. Chem. A., 3 10592-10602 (2015).

[37] S Asaithambi, P Sakthivel, M Karuppaiah, K Balamurugan, $\mathrm{R}$ Yuvakkumar, M Thambidurai, G Ravi, J. Alloys. Compds, 853157060 (2021).

[38] Md. Tamez Uddin, Md. Enamul Hoque, M.C. Bhoumick, RSC Adv., 1023554 (2020). 
Figures

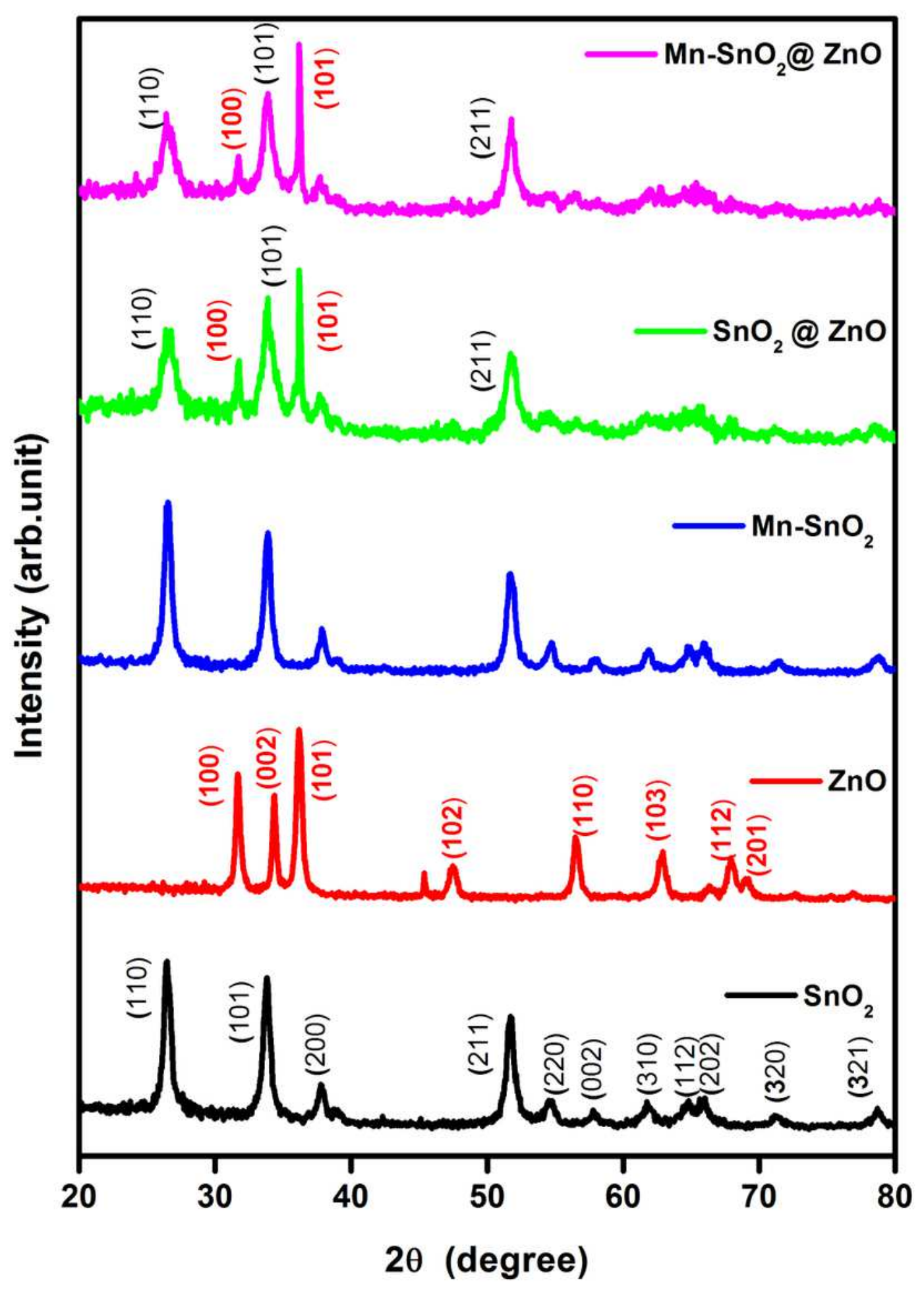

Figure 1

PXRD pattern of synthesized SnO2, ZnO, Mn-SnO2,Sn02@ZnO and Mn-Sn02@ZnO composite samples. 


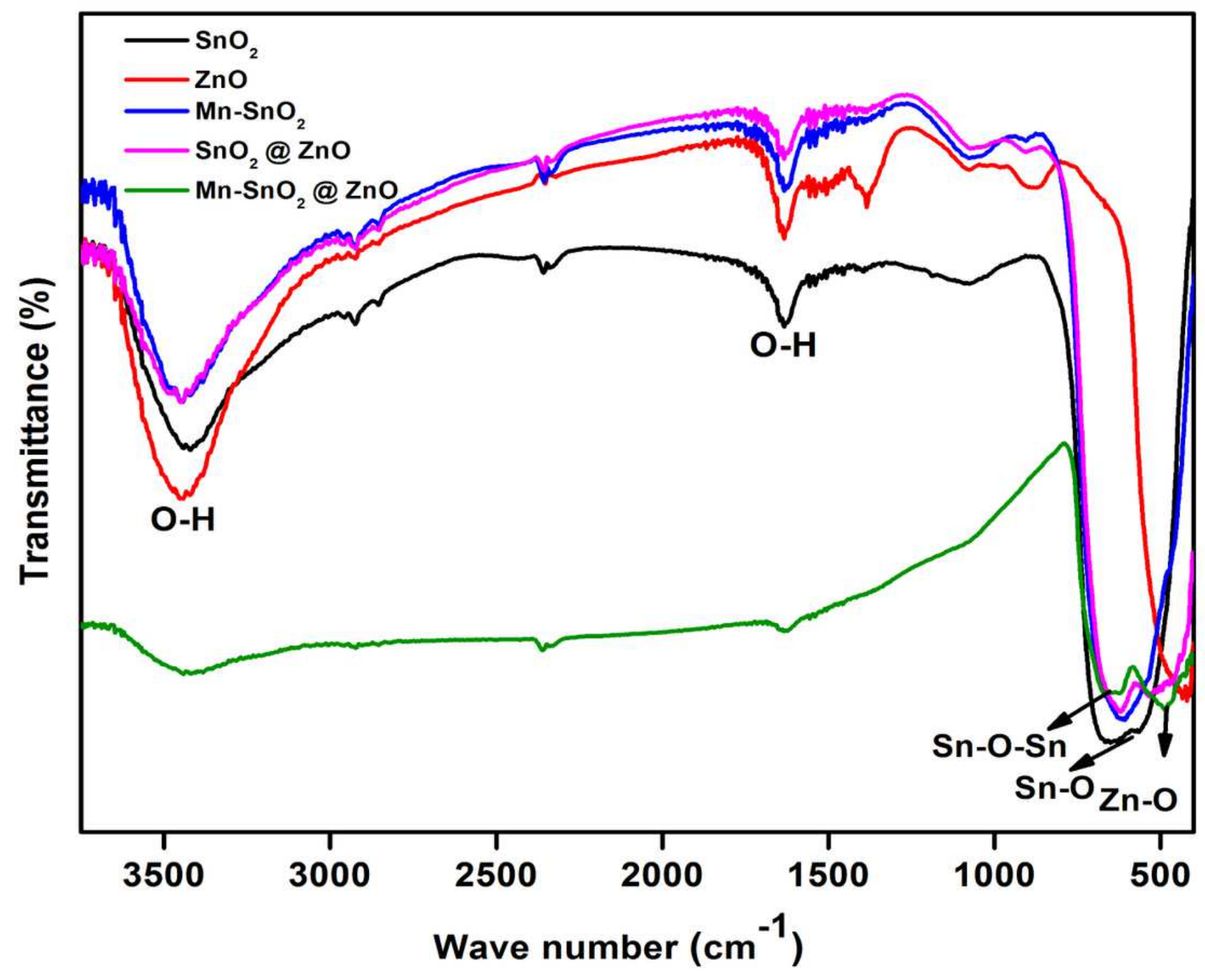

Figure 2

FTIR spectra of the synthesized SnO2, Mn-Sn02, ZnO, SnO2@ZnO and Mn-SnO2@ZnO composites samples. 

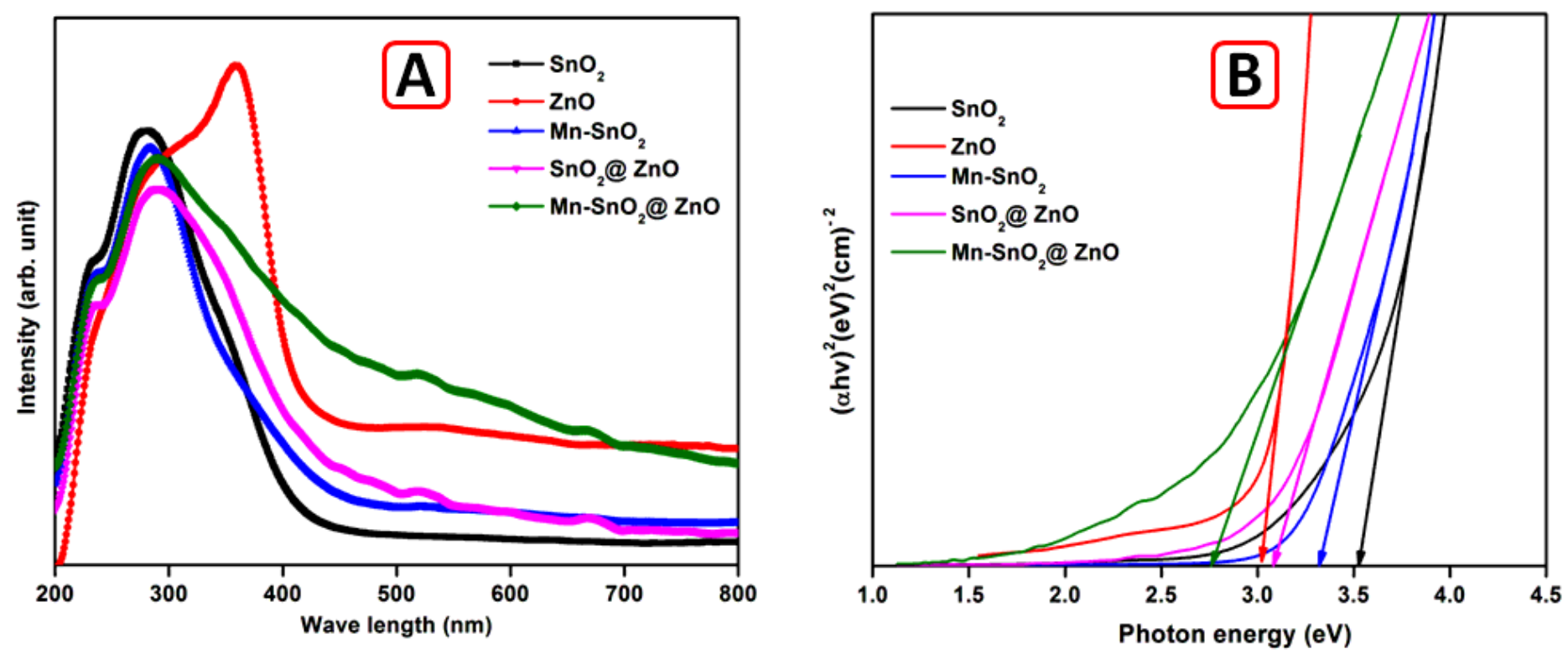

Figure 3

(A) UV-visible absorption spectra, (B) Tauc plots of synthesized SnO2, Mn-SnO2, ZnO, SnO2@ZnO and Mn-SnO2@ZnO composite samples. 


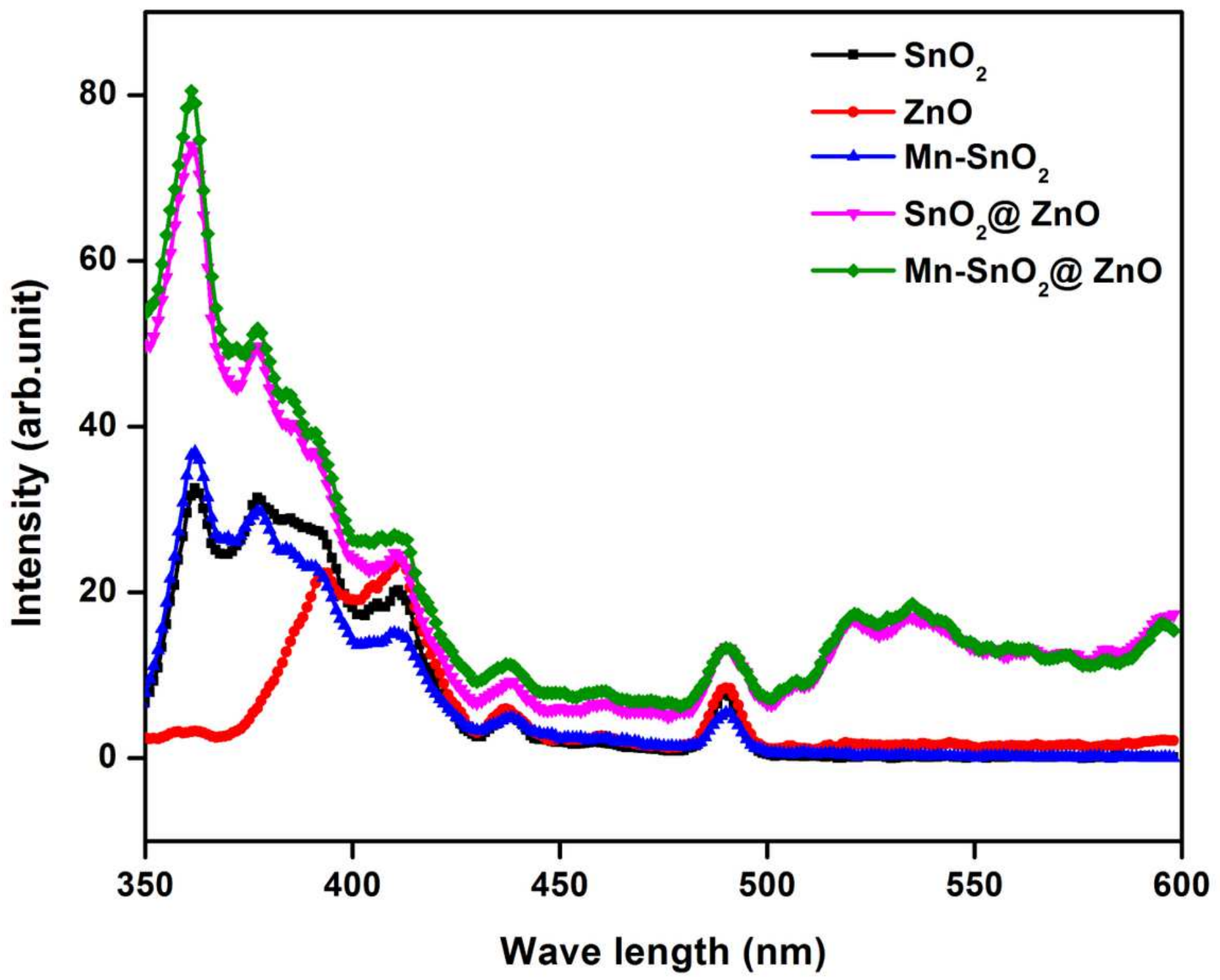

Figure 4

Photoluminescene spectra of synthesized SnO2, Mn-SnO2, ZnO, SnO2@ZnO and Mn-SnO2@ZnO composite samples. 

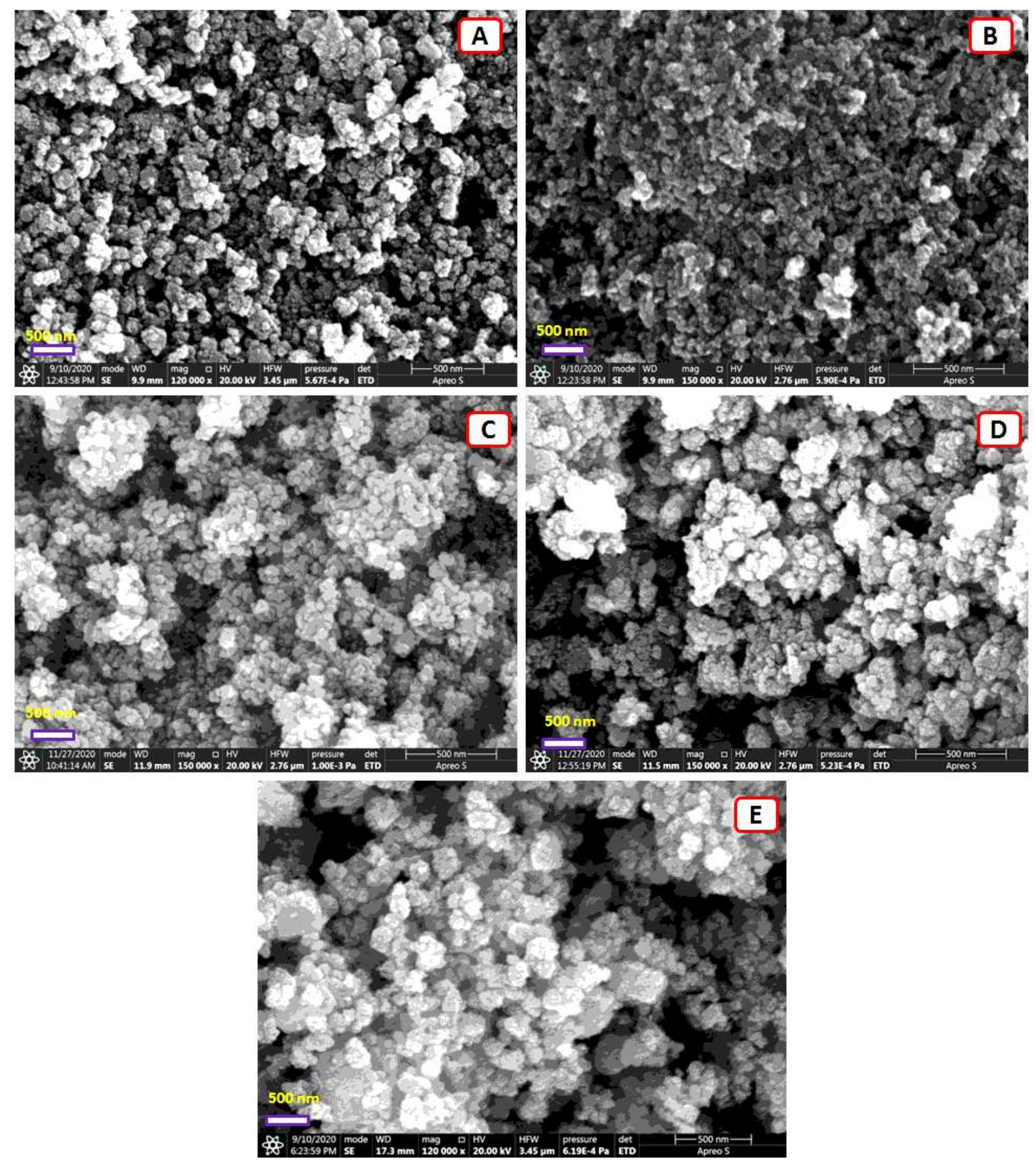

Figure 5

FE-SEM images of synthesized (A) SnO2, (B) ZnO, (C) Mn-SnO2, (D) SnO2@ZnO and (E) Mn-SnO2@ZnO composite samples. 

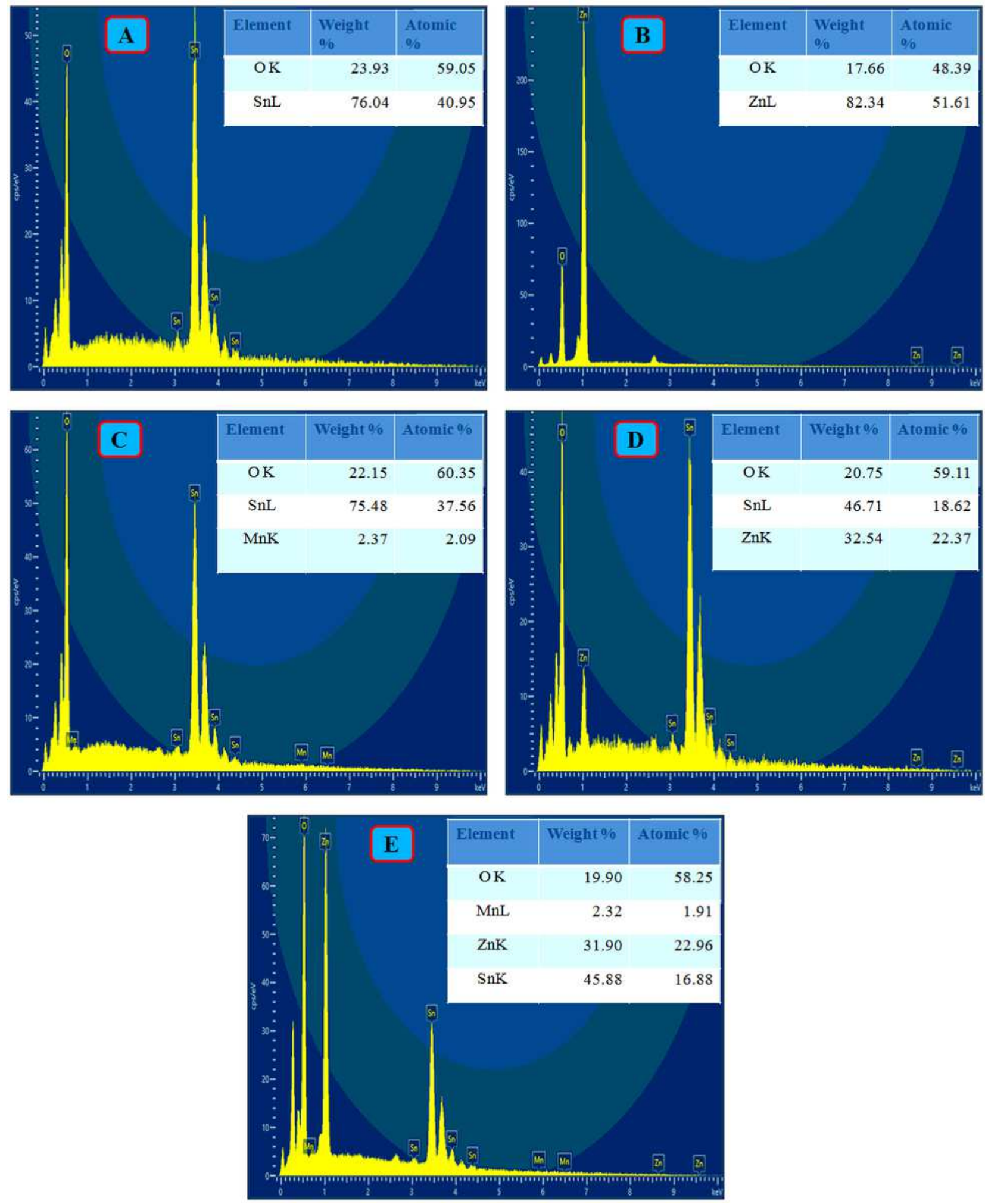

\section{Figure 6}

EDS spectra of the synthesized (A) SnO2, (B) ZnO, (C) Mn-SnO2, (D) Sn02@ZnO and (E) Mn-SnO2@ZnO composite samples. 

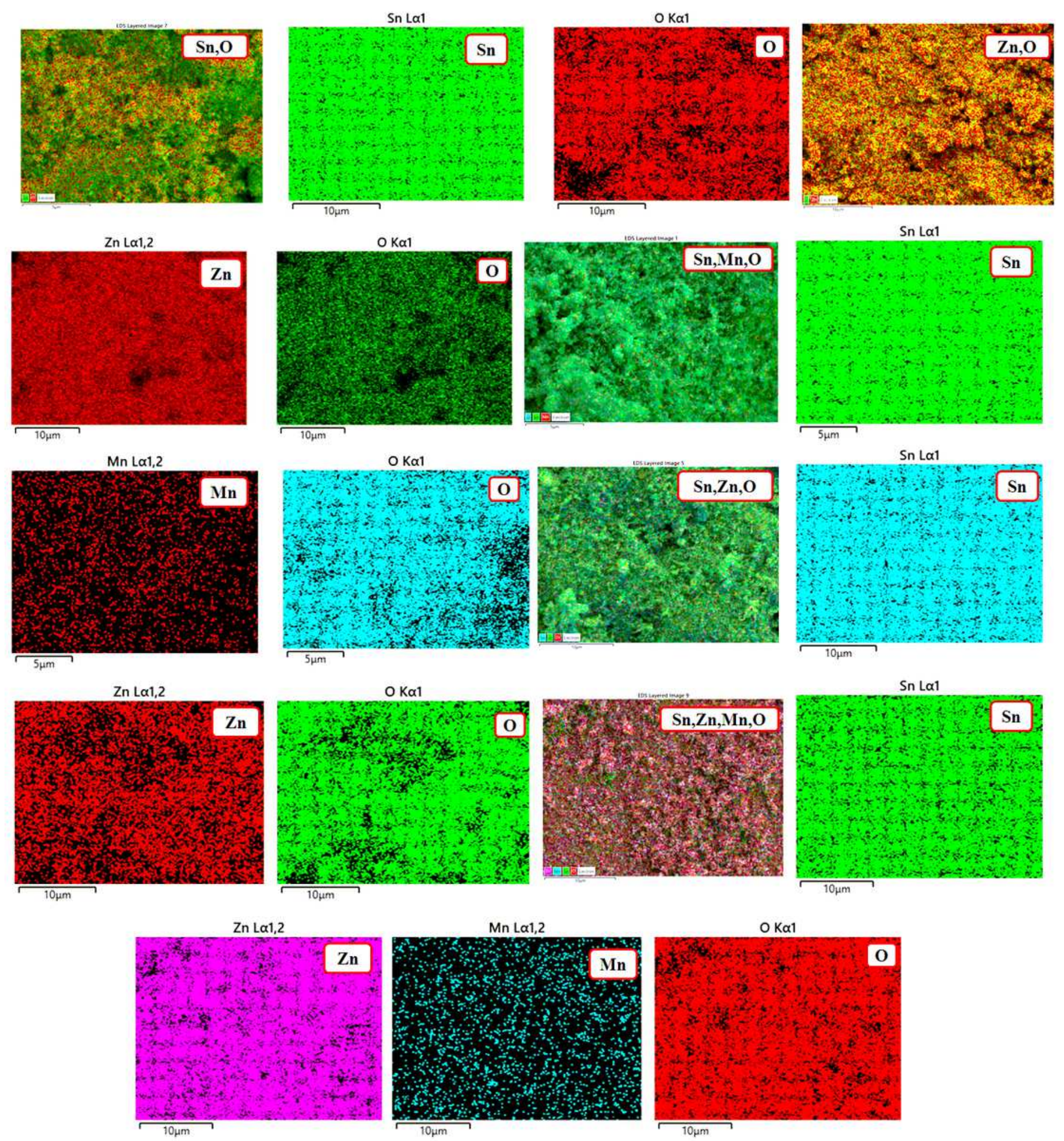

Figure 7

Element mapping of the synthesized SnO2, ZnO, Mn-SnO2, SnO2@ZnO and Mn-SnO2@ZnO composite samples. 

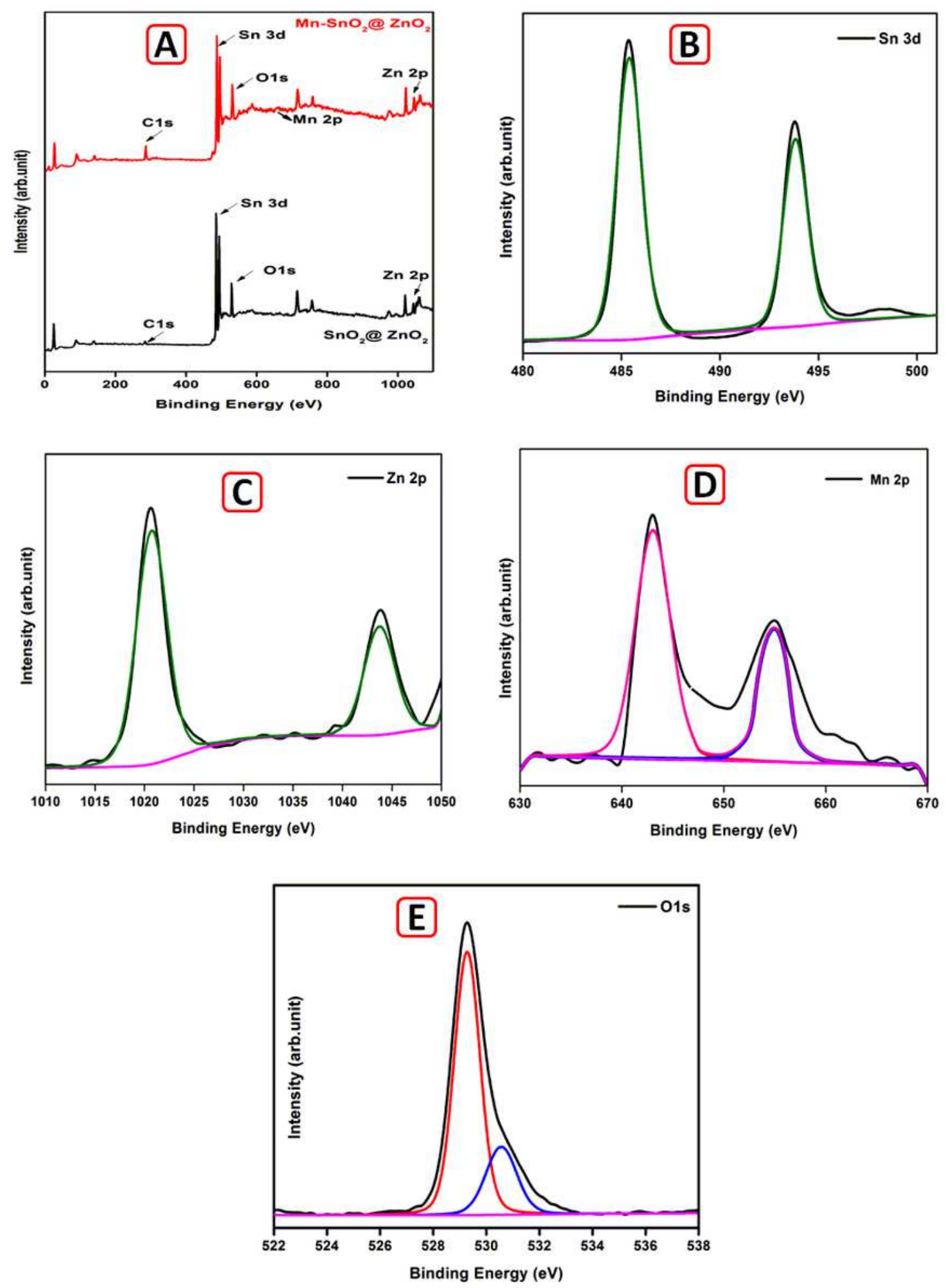

\section{Figure 8}

(A) Survey spectrum of Sn02@ZnO and Mn-Sn02@ZnO samples, (B-E) Wide scan spectra of Sn3d, Zn2p, Mn2p and 01s levels, respectively. 

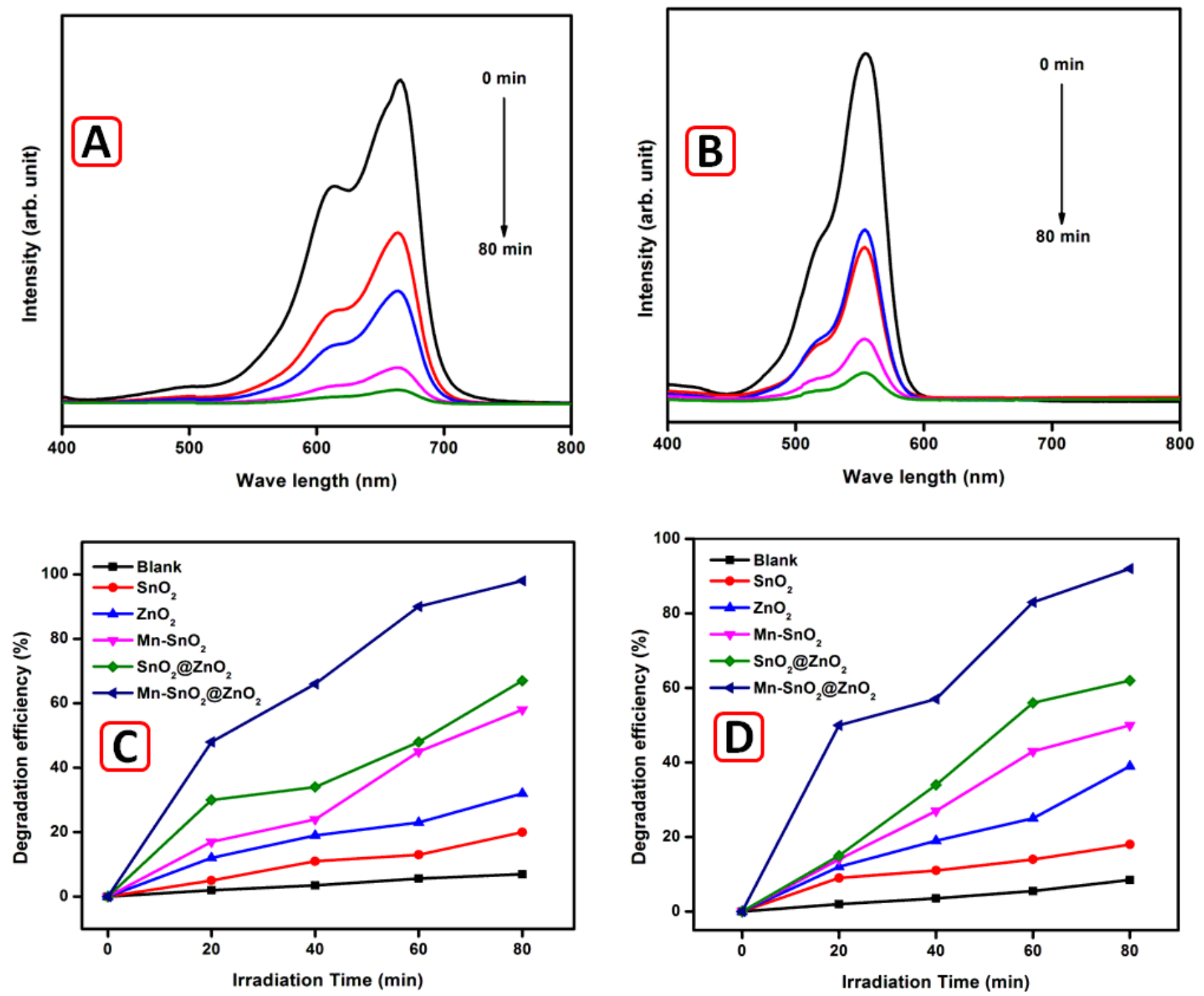

Figure 9

$(A, B)$ The changes in the absorption peaks of MB and RhB dyes for Mn-SnO2@ZnO catalysts with different irradiation time, (C, D) Photo degradation efficiency of blank, SnO2, ZnO, Mn-SnO2, SnO2@ZnO and Mn-SnO2@ZnO catalysts using MB and RhB dyes. 

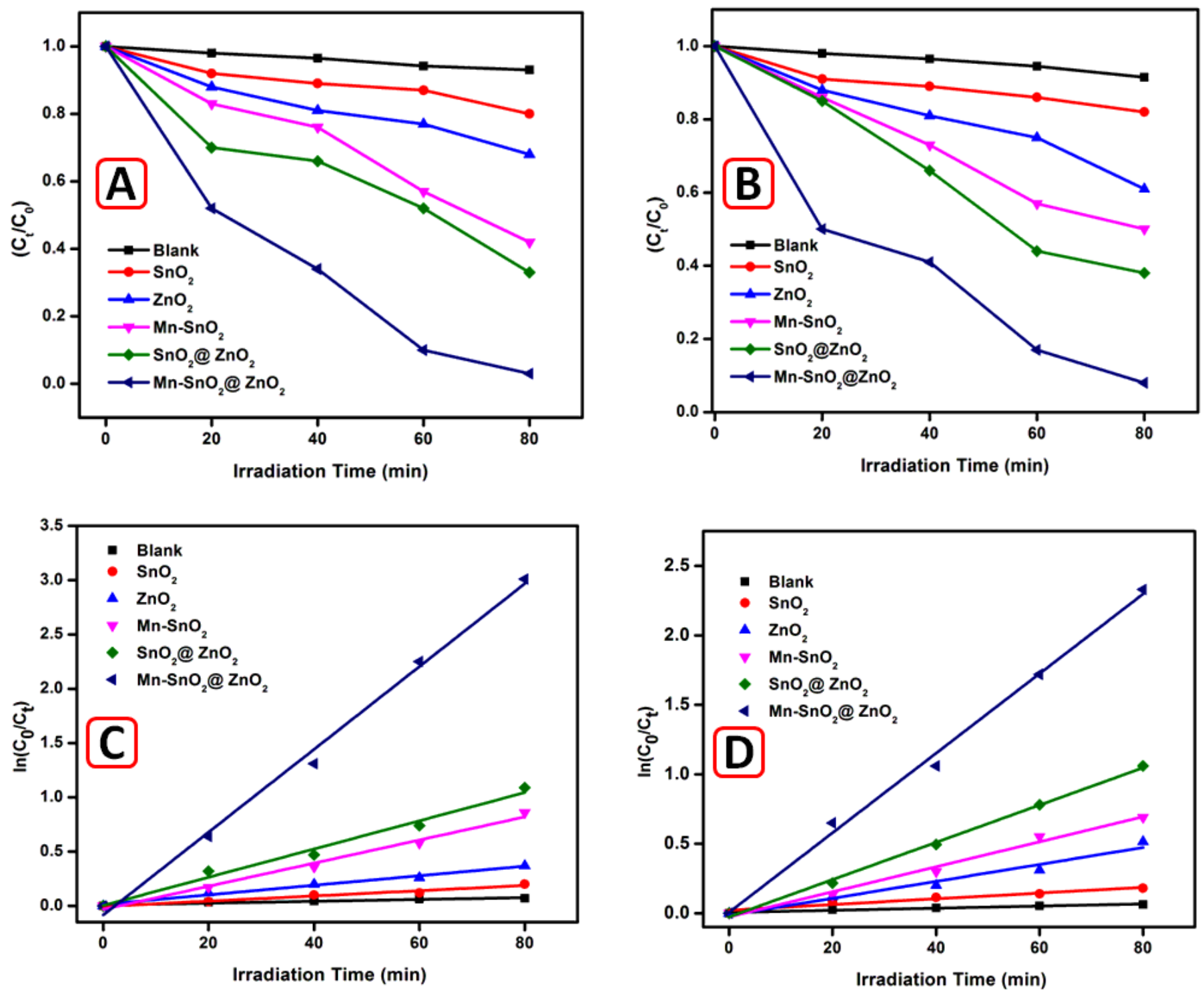

Figure 10

$(A, B)$ Degradation concentration ratio, (C, D) Kinetic study of the blank (no catalyst), SnO2, Mn-SnO2, ZnO, SnO2@ZnO and Mn-SnO2@ZnO catalysts using MB and RhB dyes with different irradiation time. 

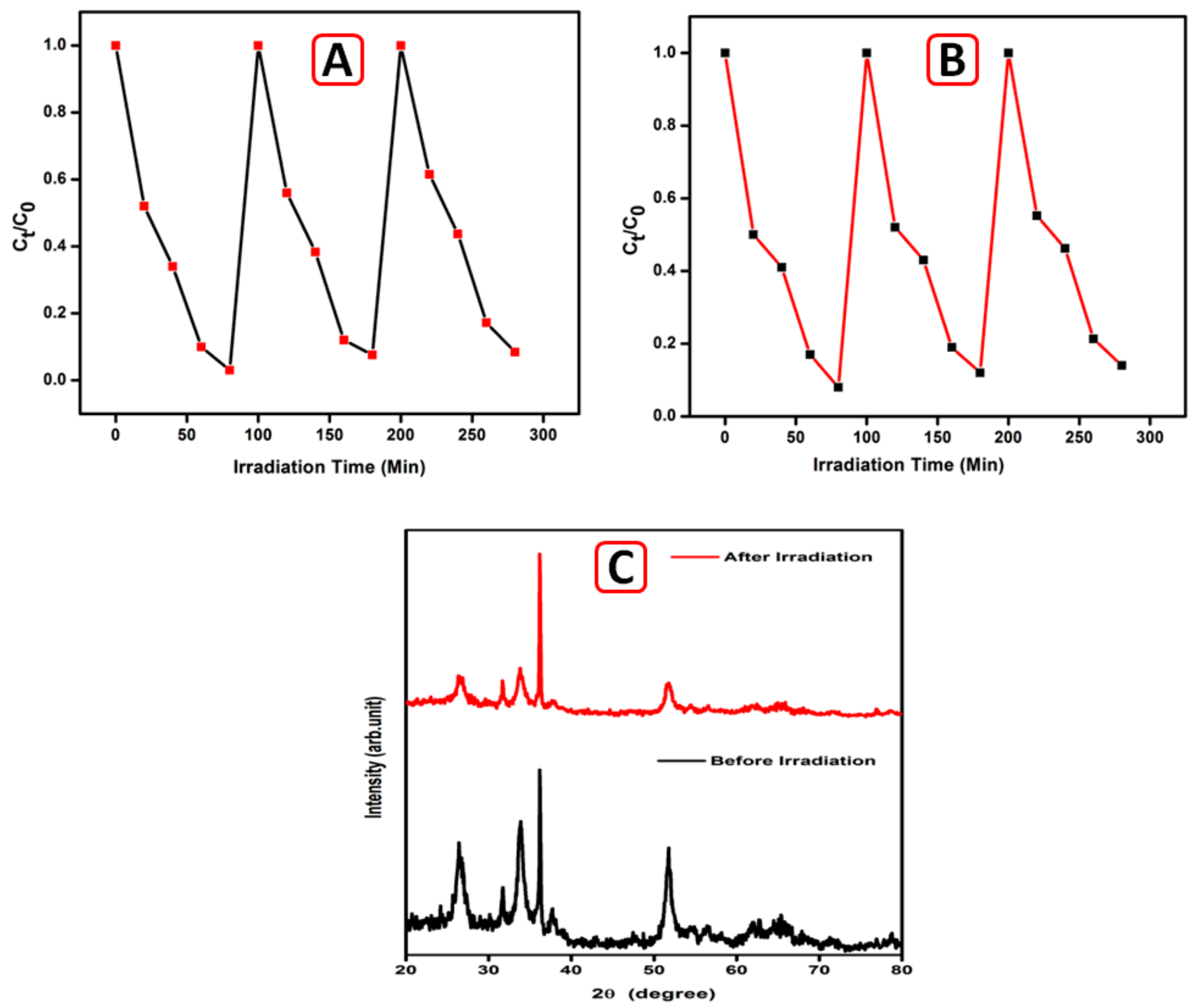

Figure 11

$(A, B)$ Mn-SnO2@ZnO catalyst stability against MB and RhB dyes upon cyclic irradiation of 80 min duration, (B) The XRD patterns of Mn-SnO2@ZnO photo-catalyst before and after the photocatalytic reaction. 


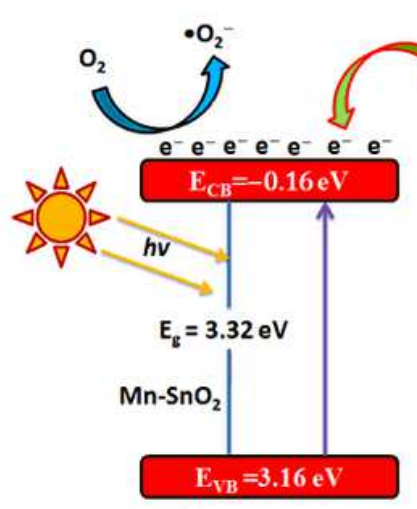

$h^{+} h^{+} h^{+} h^{+} h^{+} h^{+} h^{+}$
A

$\mathbf{e}^{-} \mathbf{e}^{-} \mathbf{e}^{-} \mathbf{e}^{-} \mathbf{e}^{-}$

$\mathrm{E}_{\mathrm{CB}}=-0.21 \mathrm{eV}$

\section{$\mathrm{E}_{\mathrm{VB}}=2.79 \mathrm{eV}$}

$h^{+} h^{+} h^{+} h^{+} h^{+} h^{+} h^{+}$

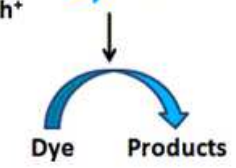

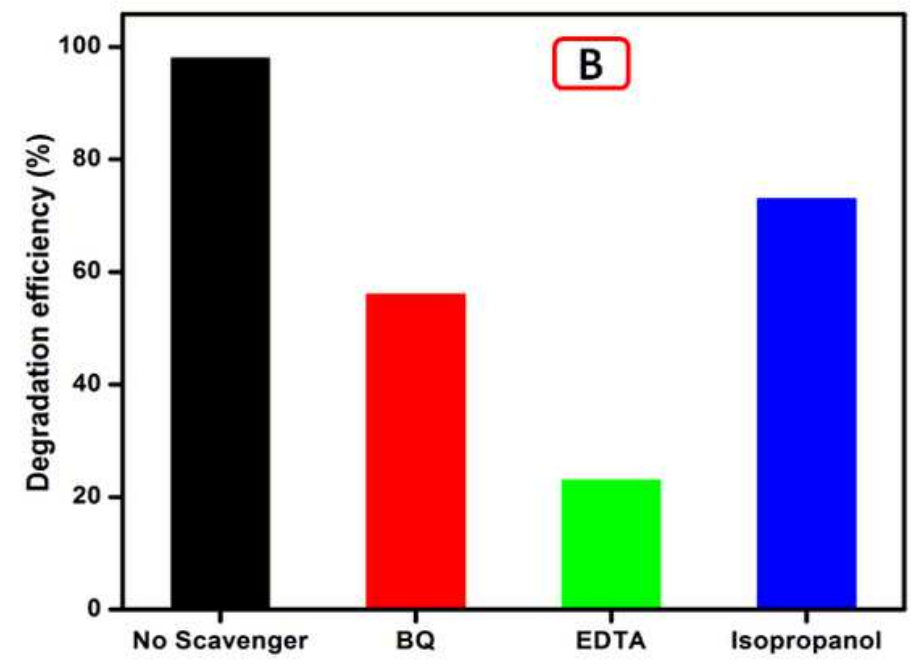

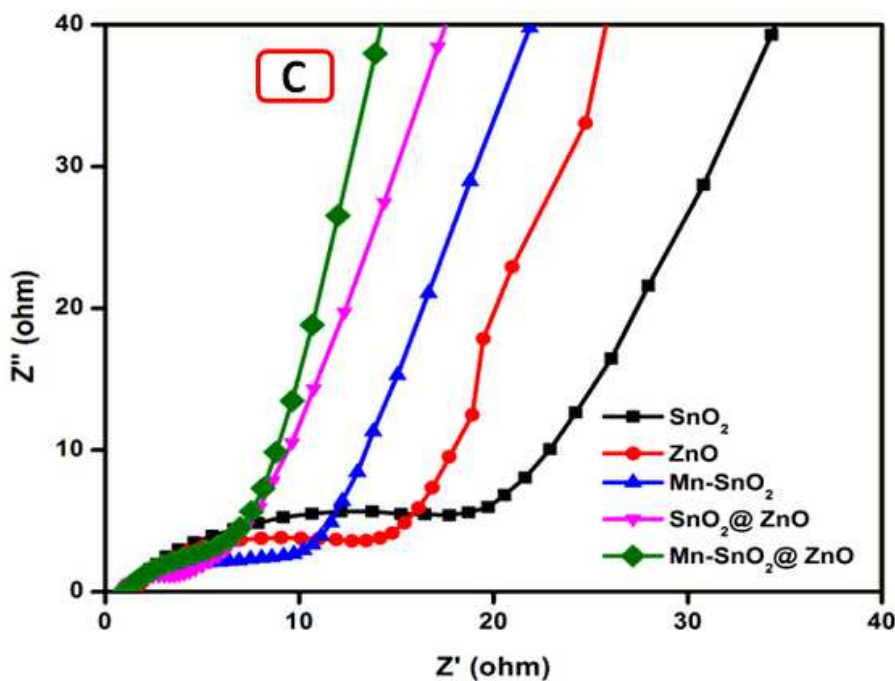

Figure 12

(A) Schematic diagram of the catalytic mechanism of Mn-SnO2@ZnO photo-catalyst, (B) Trapping experiment for the Mn-SnO2@ZnO photo-catalyst using MB dye, (C) EIS spectra of SnO2, ZnO, Mn-SnO2, Sn02@ZnO and Mn-SnO2@ZnO samples. 